\title{
OBRAS DE REHABILITACIÓN EN EL MERCADO DE ABASTOS DE LA CIUDAD HISTÓRICA DE SANTIAGO DE COMPOSTELA
}

\author{
(REHABILITATION WORKS ON THE PROVISION MARKET OF THE HISTORIC CITY OF \\ SANTIAGO DE COMPOSTELA)
}

Julián Morenas Aydillo, Arquitecto

ESPAÑA

Fecha de recepción: $30-$ VI-95

\section{RESUMEN}

El valor histórico de lo que significaban las mercaderías de abasto, tanto en Santiago como en los distintos puntos de nuestra geografia, puede sintetizarse a través del estudio llevado a cabo en dicha ciudad mediante las distintas obras de rehabilitación de su Mercado de Abastos.

Se hace una descripción pormenorizada del enclave de este Mercado -a mediados del XIX-, de las consecuencias de su emplazamiento y del choque ambiental producido. Finaliza este articulo comentando la obra de Vaquero Palacios sobre el estado del actual Mercado y las obras de intervención y rehabilitación realizadas.

\section{SUMMARY}

The historic value of the provision markets, both in Santiago and in other places in Spain, can be synthetized in a study carried out in Santiago through different works of rehabilitation of its Provision Market.

A detailed description is given of the Market grounds -in the mid-XLX century-, of the consequences of its location, and the environmental shock produced. The article ends by commenting on the work of Vaquero Palacios on the present state of the Market and the rehabilitation actions taken.

\section{I.- Introducción}

¿ ¿Un precedente ochocentista en la plaza Mayor?

¿Hubo preocupación en la Compostela del ochocientos por dar respuesta global a un tema, habitualmente disperso, como fue la existencia de diversas mercaderías de abastos en las distintas zonas del entonces casco histórico?.

Sabemos que este tema fue resuelto por medio de formas urbanas centralizadas, tanto en Santiago como en otras ciudades del país, hacia el último tercio del XIX (1). ¿No resulta prematuro adelantar este planteamiento al siglo precedente?. También es conocido, cómo con la puesta en vigor de las "Ordenanzas de Policía de 1780 de Santiago de Compostela" (2), se inicia la transformación de la ciudad precedente. Acaso, en aquella urbe, todavía medieval en la mayor parte de su extensión urbana (3), ¿llegó a plantearse el dotar a la ciudad de un mercado centralizado de abastos en época tan temprana?.

No se pretende dar respuesta a cuestiones históricas escasamente documentadas en este momento; tan sólo ha parecido oportuno, por el interés que este tema puede suscitar, mostrar cómo en julio de 1787 (4), el Consistorio santiagués, presidido por el alcalde Joaquín María Bermúdez, aprueba el proyecto de Mercado de Casetas portátiles, para situarlo en la relativamente recién conformada plaza Mayor de la Ciudad (5), hoy conocida como plaza del Obradoiro. Suscrito por el gran arquitecto neoclásico Miguel Ferro Caaveiro (1740-1807) (6), se muestra en las cuatro primeras figuras.

Se desconoce la vida o inexistencia que llegó a tener este proyecto, no obstante, su relación temâtica con el objetivo de este artículo y el detalle constructivo expuesto, le hacen 


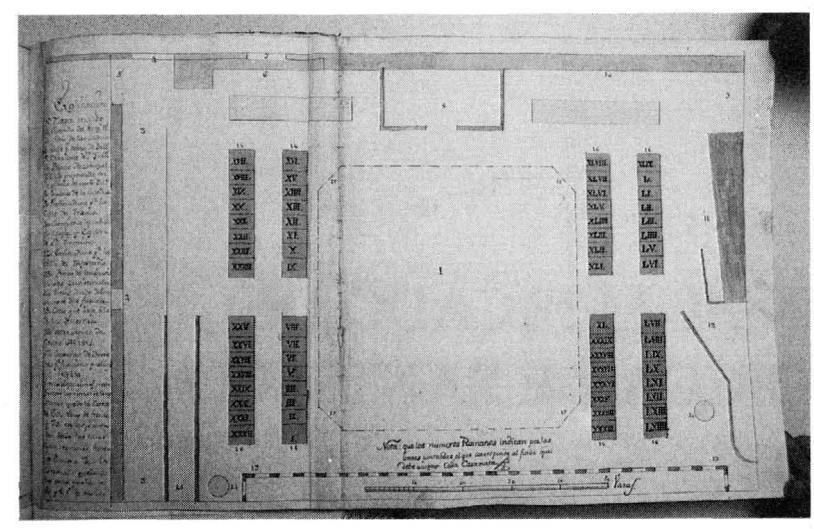

Fig. 1.- Planta de ordenación para la fábrica de casetas portátiles en la plaza Mayor de la ciudad (1787).

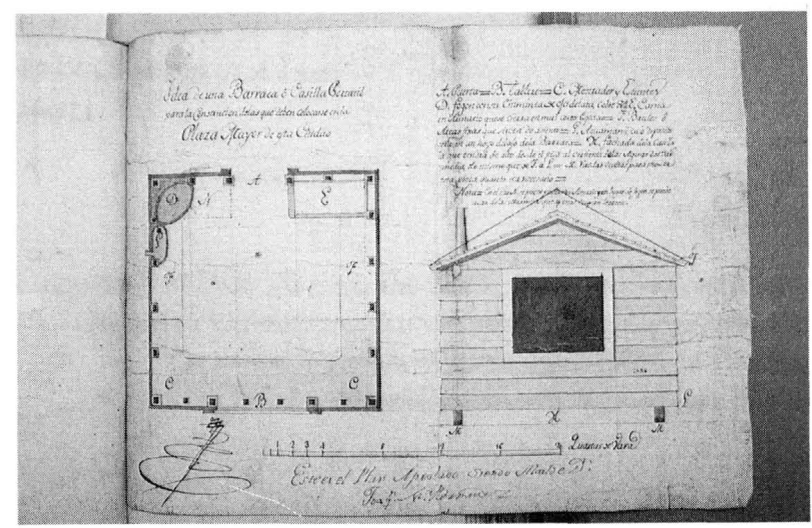

Fig. 3.- Propuesta inicial de casetas móviles, suscrita por el arquitecto M. Ferro Caaveiro

merecedor de esta breve exposición. Cabe citar como singularidad constructiva cómo con un solo material, la madera, debidamente trabada, se solucionaban todos los elementos constructivos: suelo, techo, paredes y su condición rodada.

Aunque la disparidad con el mercado decimonónico, más adelante expuesto, es evidente, cabe mencionar elementos semejantes, tales como la regularidad de su planta de ordenación, con 64 casetas en torno a un gran espacio central, de aproximadamente $50 \times 58 \mathrm{~m}$, que relacionaría Catedral y Consistorio. Por otro lado, sorprende la amplitud de las casetas ochocentistas, sobre $10 \mathrm{~m}^{2}$, frente a las pequeñas unidades de $6 \mathrm{~m}^{2}$, del mercado decimonónico, coincidentes con las del mercado actual.Esta pequeñez justifica las agregaciones de casetas que hoy día se vienen produciendo.

\section{-El antecedente decimonónico (co. 1870-7.3)}

No fue hasta los primeros setenta del XIX, cuando la Compostela de mercadillos dispersos (7), cuyas actividades han quedado en algunos casos reflejadas en el topónimo

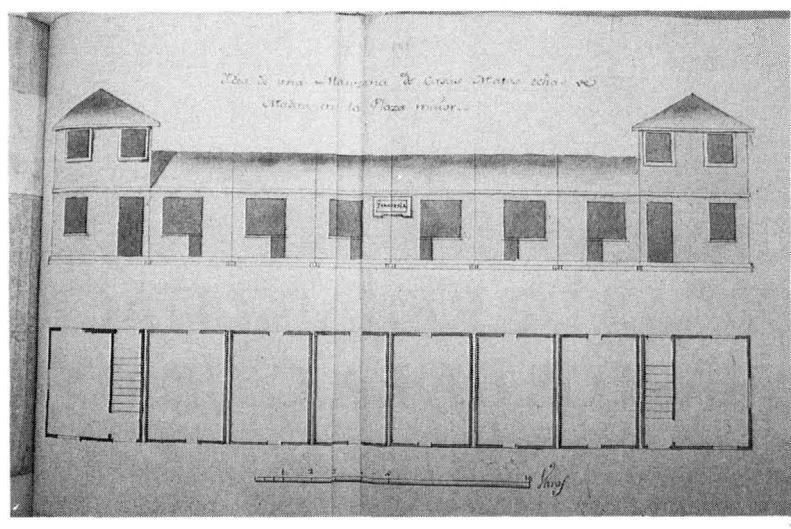

Fig. 2.- Alzado parcial de un frente de casetas.

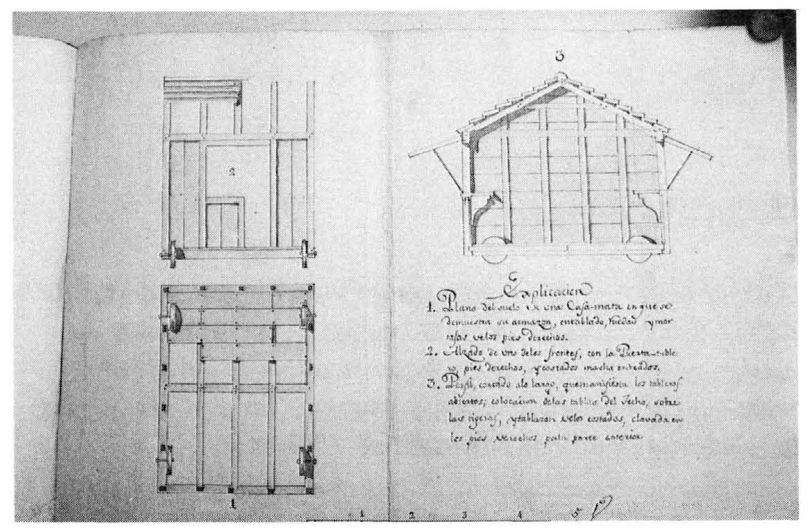

Fig. 4.- Detalle constructivo de suelo, frente y sección de una "casa mata".

de algunas plazas, como Mazarelo (8) y Pescadería Vieja, distribuidas en distintos lugares del casco histórico de la época, dio paso a la Compostela del centralizado y gran Mercado de Abastos. Proyectado por el arquitecto coruñés Agustín Gómez Santamaría (i -1871), y situado en los terrenos del Pazo, ya obsoleto, y huertas que fueron del conde de Altamira, entre las iglesias de S. Fix de Solovio (S. Félix) y la de S. Agustín(Fig. 5), en el lado naciente del recinto histórico, fue construido a partir de 1870 por el destacado maestro de obras Manuel Pereiro Caeiro (18331909) (9), sobre una extensión de $5.000 \mathrm{~m}^{2}$.

Conociendo la traza urbana precedente, cabe imaginar el fuerte impacto ambiental de este mercado. El plano de emplazamiento de la zona, suscrito en 1832 por el arquitecto municipal M. Prado y Vallo, para situar en la parte posterior de las huertas citadas, el entonces proyectadoy no construido por él mismo, Mercado de Pescaderías (11), aporta un conocimiento detallado del lugar. La superposición sobre el mismo de la traza del mercado decimonónico(Fig. 6), da idea de lo que fue la intervención urbana más radical, habida en el XIX, en el recinto histórico medieval precedente. 
Los planos del autor Fig. 7) y la foto inédita de principios de siglo (Fig. 8), conjuntamente con las difundidas por otras publicaciones (10), nos dan una idea clara de este gran Mercado que, de forma tan peculiar, como veremos, se relaciona con el existente.

Desde el punto de vista del espacio público, tuvo lugar la pérdida, entre otras cosas, de un sinuoso callejón con muro almenado y pasadizo cubierto, que lo comunicaba con la plazuela de la Pescadería Vieja, frente a la adquisición de seis calles paralelas y regulares a la entonces llamada Picho de la Cerca (hoy Virgen de la Cerca), de las cuales cuatro, cubiertas, estuvieron articuladas por la plazoleta central del mercado, dotado de fuente pública. Es de mencionar el carácter de espacios públicos y abiertos de que dispuso este mercado, siendo citadas por el propio autor en su memoria como "calles cubiertas", frente al conjunto enrejado del mercado actual.

\section{-El Mercadó actual de Vaquero Palacios (co.1940-43)}

La almendra del casco histórico, asíllamada recientemente por algunos autores el hoy recinto ex-amurallado de la Compostela histórica, con una extensión de 29,2 ha, dispone, en su perímetro naciente, con frente a la calle Virgen de la Cerca del actual Mercado de Abastos (Fig.9). Proyectado en 1937 por el arquitecto asturiano Joaquín Vaquero Palacios, y construido en los primeros cuarenta, en el mismo lugar que el precedente decimonónico, supuso un ejemplo de obra maestra en sí misma y de ambientación con el entorno. Los planos del autor (Fig.10) nos muestran su ordenación.

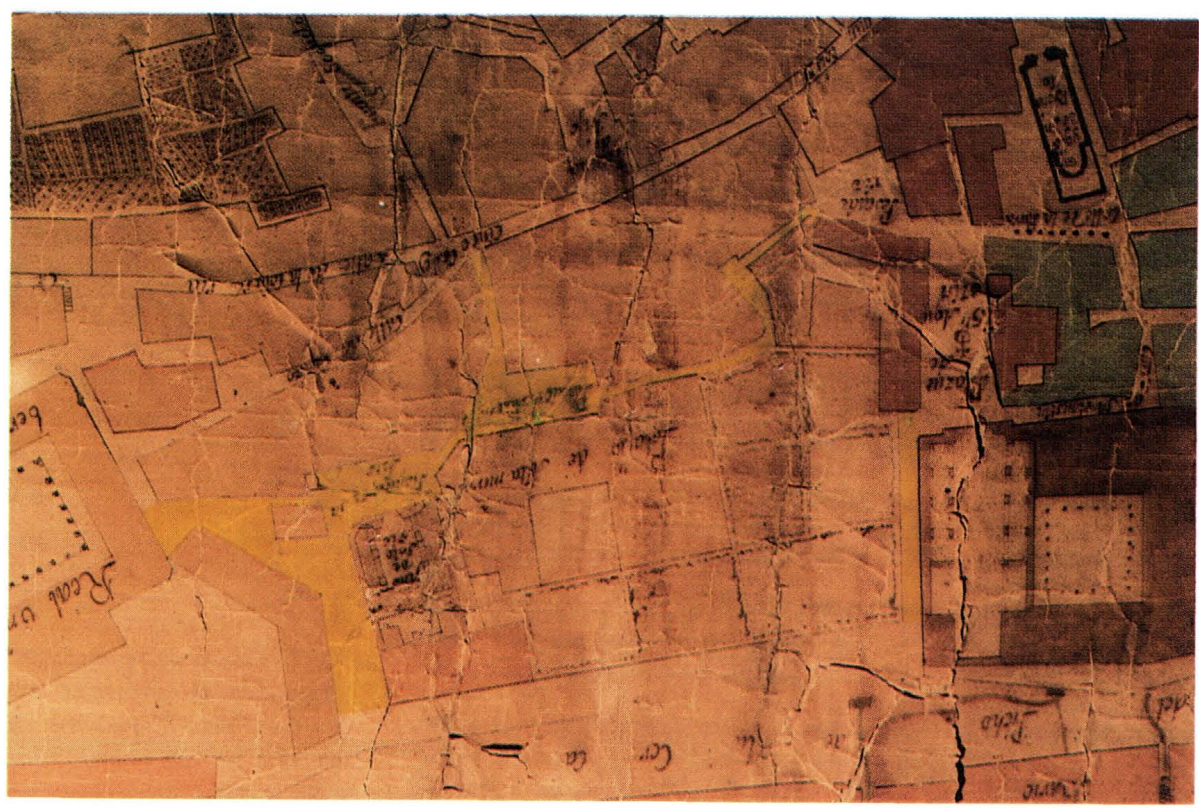

Fig. 5.- Plano parcial de la ciudad, de 1783, mostrando la traza urbana y el estado ochocentista del Pazo y huertas muradas del conde de Altamira.

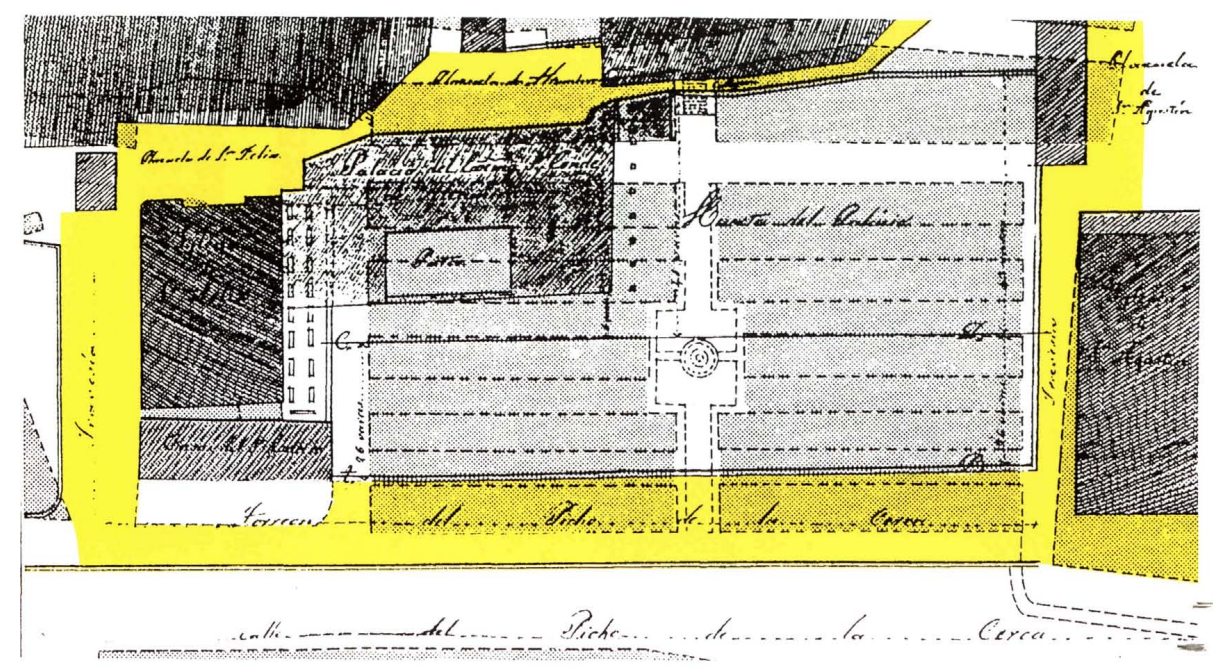

Fig. 6.- Superposición de la planta del Mercado decimonónico, sobre la trama urbana precedente. 

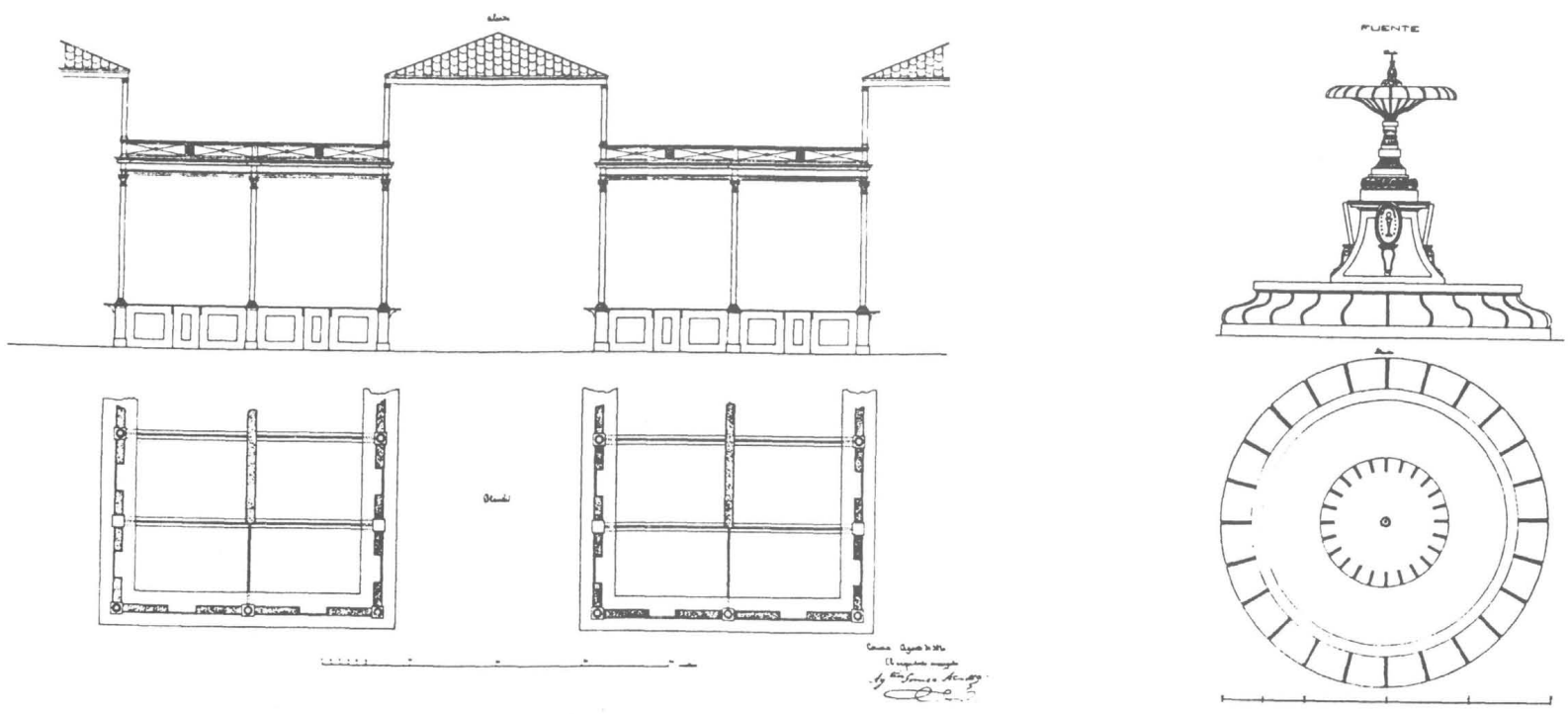

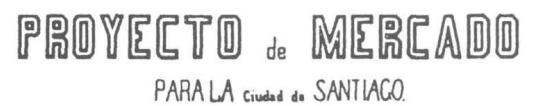

alrado lougluamal.
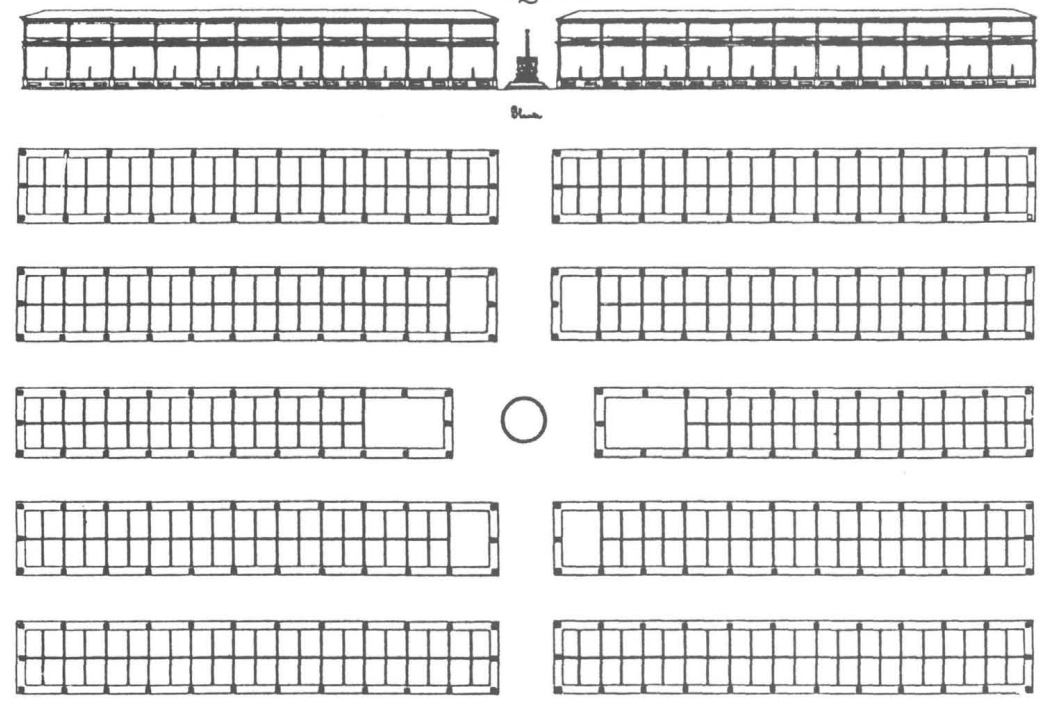

Fig. 7.- Planta de ordenación y alzados principales del proyecto decimonónico, suscrito por el arquitecto Agustín Gómez Santamaría en 1870. Fuente monumental de mármol blanco del mismo proyecto que, en su día, ocupó el espacio central del Mercado y hoy se encuentra en el parque de la Herradura.

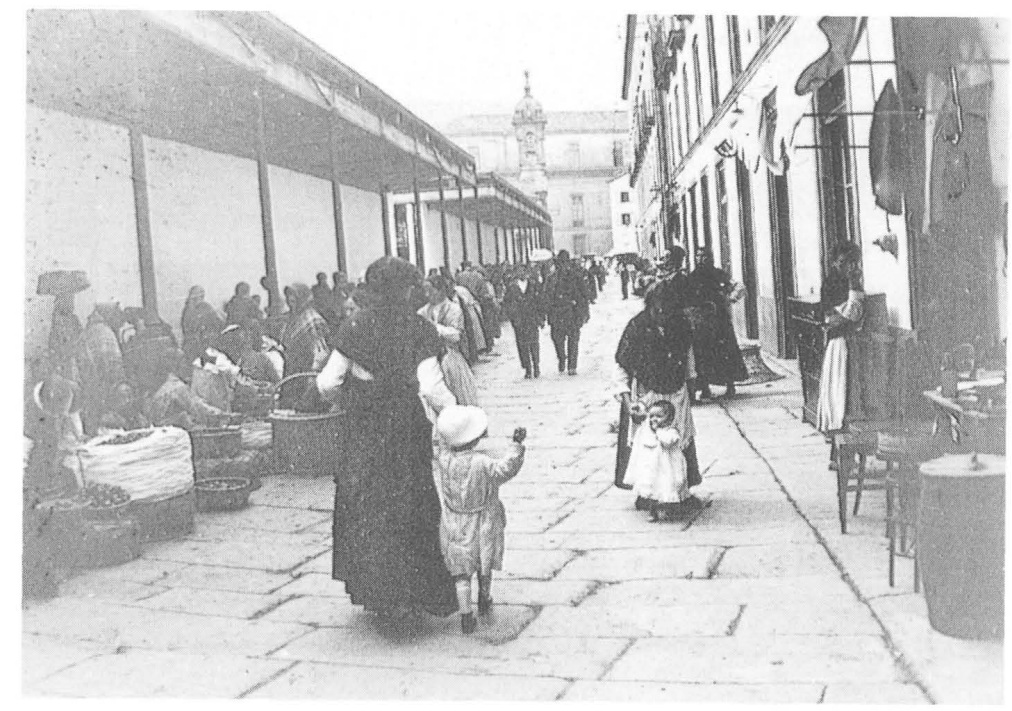

Fig. 8.- Foto del Mercado decimonónico, hacia 1910. (A. p. de Antón Barba). Foto: Mari Vila. 


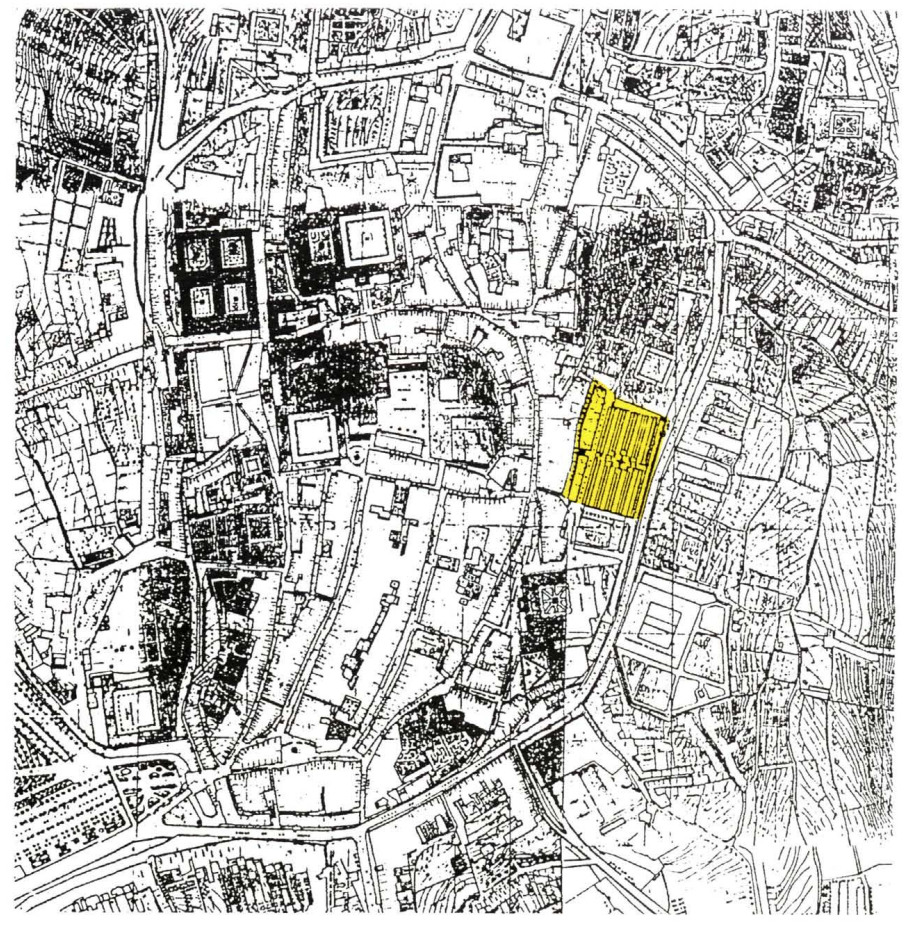

Fig. 9.- "Almendra" del casco histórico, según plano de 1908, levantado por los ingenieros Laforet, Cánovas y La Gándara.

Nada más grato que añadir la ordenación constructiva que el propio autor evoca en la emotiva carta que dirige a José Ignacio, para ser publicada en la revista, hoy desaparecida "Composición Arquitectónica"(12).

\section{Querido José Ignacio:}

Me pides una carta que explique un poco mis vivencias en Santiago de Compostela y cómo se produjo, cómo se desarrolló esta obra mía del Mercado de Abastos, iniciado por los años treinta. Me pides esto ahora, en los años ochenta, y estoy tratando de escribirla; pero a los cincuenta años trascurridos desde entonces, se me han olvidado muchas cosas, tal vez fundamentales. Perdona, pues, por los fallos en que pudiera incurrir.

A pesar de la vecindad de Galicia con Asturias - mi tierra-, yo no conocí aquella región sino hasta después de haber andado por Europa y por América durante varios años, ocupándome de mi pintura, de arquitectura, de casarme, de vivir...cosa que va muy acorde con mi condición de astur.

Al regresar, conocí Galicia, y el impacto que me produjo la arquitectura gallega fue tremendo, y no sólo la arquitectura, sino el paisaje, el clima, el cielo, la gente con su carácter, su vida, todo tan fundido, tan homogéneo, tan acorde con sí mismo.

Santiago de Compostela me sedujo con tal fuerza y tal dulzura que me quedé varios años alli.

Y cité más arriba el término "arquitectura" y hubiera preferido decir arquitectura popular, abarcando toda su arquitectura, la de los pueblos y la de las ciudades, porque la arquitectura de Santiago, grandiosa, monumental y erudita, ponderada unas veces y disparatado otras, siempre de máxima categoría, tiene para mi un cierto sabor de arquitectura popular, llena de intimidad, da calor humano, algo entrañable, acogedor, cualidades ausentes, no pocas veces, en la arquitectura monumental.

Entusiasmado de Galicia, recorrísus caminos, visité sus aldeas y sus ciudades, cambié impresiones con sus gentes, escuchando su lenguaje musical, sus sentencias impregnadas de una filosofia profunda, y en mis recorridos fui atraido muy particularmente por la abundancia y la diversidad de granitos que existen y por el inteligente y hábil aprovechamiento que los gallegos hacen de ese precioso material, extrayéndolo de sus canteras por medio de cuñas en lajas de diversos espesores cantantes.

Con este "perpiaño", como se llama, construyen su arquitectura vital, ni la más pobre ni la más rica, hasta sus ermitas, sus iglesias más sencillas.

Llegan a tal habilidad en la extracción de piedras que obtienen prismas hasta de diez por diez centímetros de sección y más de dos metros de longitud, que emplean para sus emparrados como si fueran palos.

No sé explicarte la sensación que me producía ese contraste entre la pobreza de algunos pequeños pueblos o caseríos y la riqueza del granito, manejado con los minimos medios y con una sencillez tan admirable como asombrosa.

Con todas estas impresiones y el sinnúmero de dibujos que hice portodas partes llegué a sentirme totalmente compenetrado con aquella tierra.

Recibi entonces en Santiago varios encargos de arquitectura, algunos oficiales y otros particulares, pero el que más me 


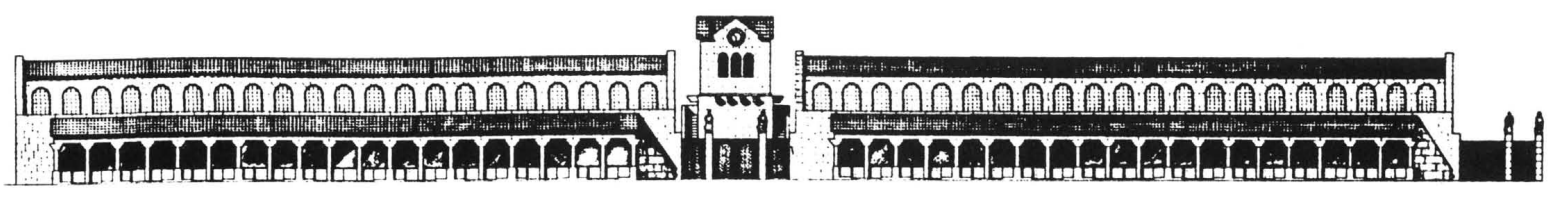

Alrado a le calle Altamira.

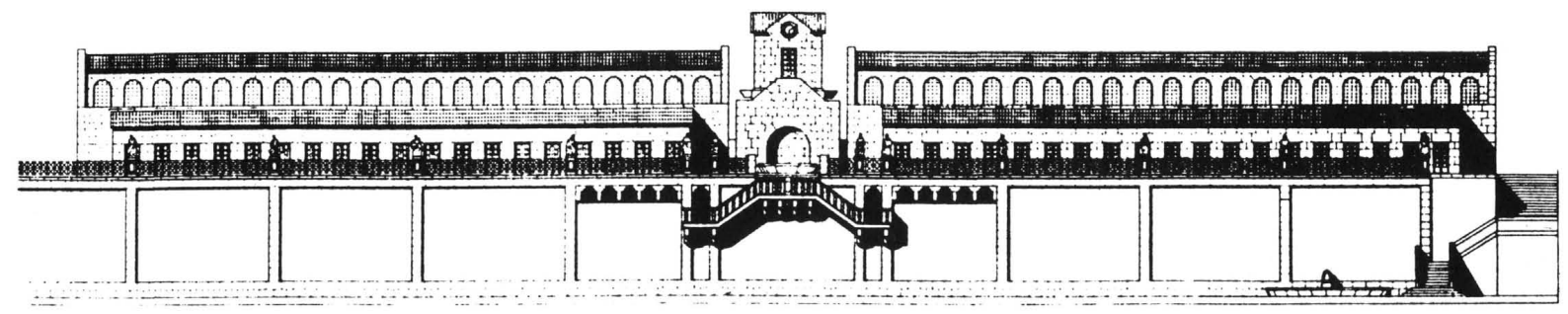

Alzado a le celle Virgen de he Cerrea.

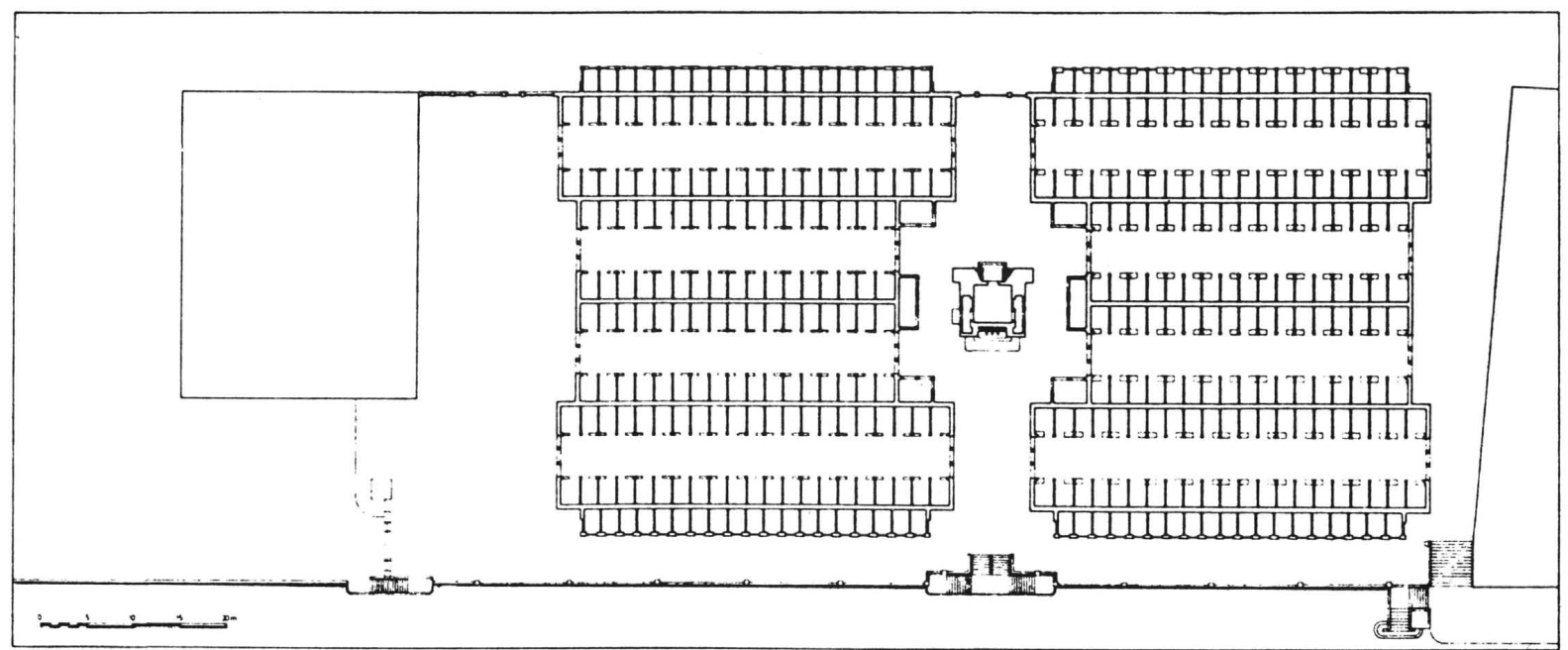

Planta general; en la parte inferior, el murallón hacia la calle Virgen de la Cerca.

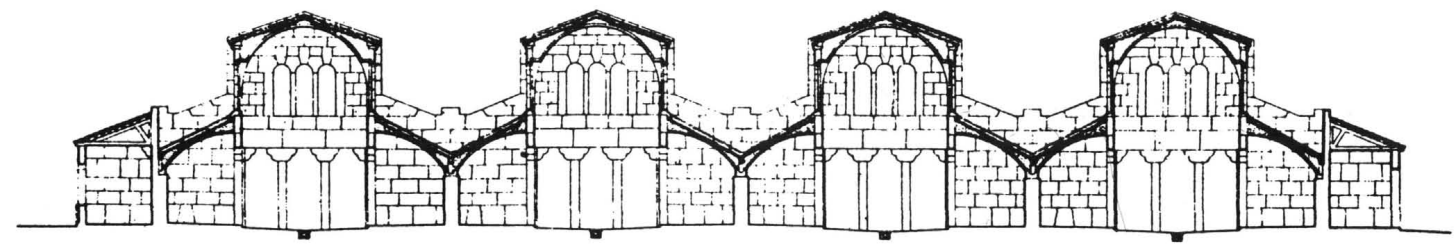

Seccion trensversel.

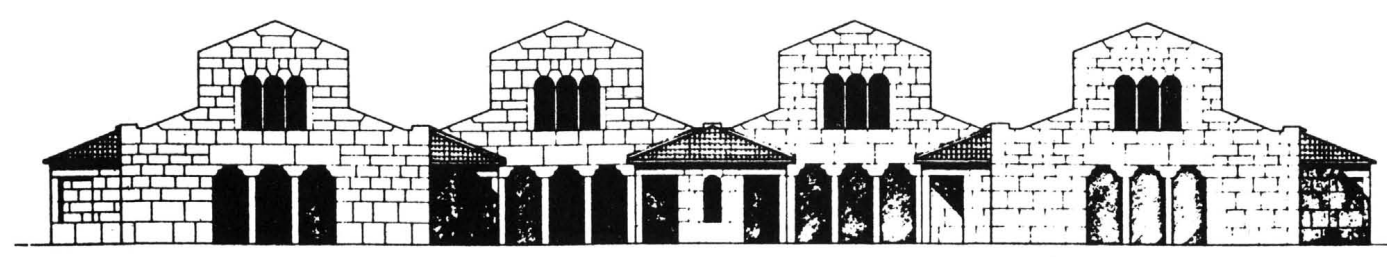

Aliedo ireworvers.

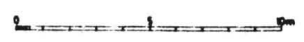

Fig. 10.- Planos del actual Mercado de Abastos, s/ proyecto de 1939 del arquitecto Vaquero Palacios. 
interesó fue el de proyectary construir un mercado municipal en el mismo solar en que se derrumbaba poco a poco, por viejo, el antiguo, un edificio "modernista", con una estructura de hierro fundido sobre muros de mamposteria, el que habria de ser demolido, con aprovechamiento de lo que buenamente se pudiera para la nueva plaza.

Pues bien, por el tema a desarrollar, algo así como realizar la integración de la aldea y del campo en la ciudad, por su ubicación entre dos preciosas iglesias, en un barrio céntrico y al mismo tiempo extremo, por la existencia de un murallón que salvaba su cota elevada sobre otro barrio de la ciudad, y por la ilusión que me hizo la idea de poder utilizar yo mismo, casi con mis manos, aquellos elementos de piedra que yo aprendi a amar en mis paseos por Galicia, acepté el encargo y puse manos a la obra del proyecto.

Me pareció que había cuatro elementos aprovechables: El trazado y la excavación, aunque mezquina, de la red general de desagües; algunas partes de los muros de mamposteria que separaban las naves; el pavimento general de losas de granitoy el murallón sobre la calle de la Virgen de la Cerca. Los dos primeros obligaban al ancho de naves y a su disposicióngeneral, aun cuando no iban a ser aparentes después; el último, por el contrario, iba a ser demasiado aparente y monótono.

A mi siempre me gustó trabajar con pies forzados, porque ellos, aunque dan una mayor dificultad al que proyecta, porque lo atan en un principio, pueden dar lugar a soluciones inesperadas y divertidas, o a economías en la obra, como sucedió con ésta. Sin embargo, es necesario tener cuidado de que no suceda lo contrario: que por aprovechar, algunas veces frivolamente, algún elemento existente, se pueda caer en pérdida de tiempo y en mayores complicaciones y, con ello, en gastos excesivos a la hora de construir.

Al proyectar, no tuve la pretensión de hacer una obra destacable por su modernidad o, contrariamente, por su imitación de algunos delos estilos tradicionales dela arquitectura santiaguesa.

Nunca fui opuesto a la integración de una obra actual (en cualquier momento de la actualidad) dentro de un conjunto arcaico. Esto puede estar muy bien y existen muchos ejemplos aleccionadores. Pero para ello deben reunirse tres condiciones: ser un arquitecto genial, saber que la obra se realiza dentro de un clima suficientemente culto y disponer de un presupuesto sin excesivas limitaciones. Yo no disponía de ninguna de estas tres premisas.

Por todas estas consideraciones, y porque fue lo que más me ilusionaba, intenté incorporar en la nueva obra aquellos elementos humildes, pero verdaderos, extraídos de las construcciones aldeanas, con lo que me pareció que un edificio funcional, realizado con aquellos medios primitivos y poblado más tarde con las gentes y los productos del campo, habria de integrarse de modo entrañable a la ciudad.

Con esta mentalidad realicé un proyecto, creo yo, en una escala intima y con un sabor entre románico y barroco, dos estilos dispares, pero que se conjugan en Santiago, diria yo que en toda Galicia.

Ese sabor general a románico es una cosa muy curiosa, y para mi evidente. Todo es un poco románico en Galicia, hasta los grelos. Los caballos, de abundante pelaje, con la cabeza y la panza un poco grandes y las patas un poco cortas, tienen todo el aire de los que aparecen en capiteles y en relieves medievales. $Y$ es muy curioso y muy verdad, porque yo he tenido experiencias que lo demuestran, que si se da un modelo en escayola a uno de los maravillosos "canteiros" gallegos para que lo pase por puntos a granito, la reproducción sale idéntica pero no se sabe por qué tiene un acento románico.

Terminado el proyecto, aprobado y adjudicadas las obras a un contratista, dio comienzo el trabajo.

Por fin, con un sol radiante como sólo lo hay, a veces, en Santiago, sobre la gran explanada que dejó el derribo del viejo mercado, habia una legión de canteiros apiconando el perpiaño. Era un concierto de repiqueteos, de sonidos diversos y ritmos cambiantes, que a mi me hacia feliz. Es algo inefable que no se lo imagina quien no lo haya escuchado, sobre todo para quien ame la piedra.

Volviendo al tema, ya sobre la marcha de las obras pude comprobar la posibilidad de aprovechar los elementos, a los que ya hice antes referencia, aunque los muros de mamposteria no eran útiles para apoyan nada por su pobre naturaleza. En el largo y monótono murallón proyecté una escalinata que, al mismo tiempo de servir de acceso a los servicios higiénicos, alegraba un poco su aspecto. A esta escalinata, no visible desde el área del mercado, como tampoco el mercado sería visible desde la calle inferior, le imprimi un carácter algo barroco para enlazarla con el caserío inferior.

La obra se fue desarrollando sin mayores obstáculos constructivos por su propia sencillez, y únicamente sufrió algunos retrasos debidos a elevaciones of iciales en salarios y precios de materiales que obligaron a las revisiones correspondientes, con su tiempo de gestión.

Hay algunas cosas en el edificio o complejo de edificios del mercado que no llegaron a hacerse, como ocurre en la gran mayoría de las obras. Merefieroadiversos motivos ornamentales. Estos, casi siempre, se quedan sin hacer, unas veces por falta de dinero al final, y las más por falta de interés y hasta por rechazo de los empresarios, a quienes ya no interesa un comino el redondeo de la obra artística, a lo que llaman "flecos" a cortar, cuando ya ven que puede funcionar para el objetivo propuesto.

Los arquitectos además siempre tropezamos, unayotra vez, con la misma piedra. Sólo mios, podría citar docenas de casos de obras inconclusas por falta de los remates artisticos.

Debemos consolarnos, sin embargo, porquedesdelaantigüedad, en los edificios más ilustres, podemos ver plintos, nichos, repisas..., vacios, para figuras y remates que nunca se hicieron.

En esta obra del mercado, me refiero a diversos pequeños bajorrelieves a labrar con el puntero en las fachadas de las naves, y a las figuras que debian de rematar las pilastras del murallón sobre la calle de la Virgen de la Cerca y sobre los pilones de las verjas de entrada al mercado. Los primeros llegué a modelarlos, y los modelos nadie sabe dónde habrán ido a parar. Los segundos, figuras exentas, hubiera yo deseado que bajo mi dirección fueran talladas en granito por aprendices de cantero y por artistas incipientes de las escuelas de arte de Santiago. Creo que hubiesen resultado esculturas nogeniales $y$ 
quién sabe), pero de lo que sí estoy seguro es de que hubiesen resultado graciosas, de carácter popular y, por supuesto, al precio de costo de la piedra.

El pueblo recibió la obra conjúbilo y lleva más de cuarenta años prestando servicio.

\section{-Reflexiones sobre la intervención}

Dos lenguajes antagónicos para el mismo uso.

Resulta extremadamente singular, cómo dos lenguajes formales antagónicos, distanciados 70 años, han dado respuesta arquitectónica adecuada a la misma actividad, basados en el respeto a su primera traza decimonónica.

Las abiertas calles, cubiertas de acero y cristal, sobre una estructura reticular de columnas de fundición, con basamentos pétreos, fueron sustituidas por largas naves de bóvedas peraltadas, de hormigón, semicerradas en sus testeros con pesados muros pétreos. A la ligera estructura decimonónica le sucede el pesado y cerrado cuerpo del mercado actual. La esbeltez de la columna de fundición, en cuya luz de vano se situaban dos tiendas, frente a la unidad repetitiva de voluminosos pilares, capiteles y dinteles de piedra de cada tienda. A una intervención arquitectónica de vanguardia, de la época (13), totalmente ajena al carácter histórico-artístico del lugar, le sucede otra depurada arquitectura, que constituye una lección magistral de arquitectura integrada en el entorno. Su autor, modestamente, ya lo ha expresado así “... realicé un proyecto, creo yo, en una escala íntima, con sabor entre románico y barroco, dos estilos dispares, pero que se conjugan en Santiago, diría yo en toda Galicia...". El campanario

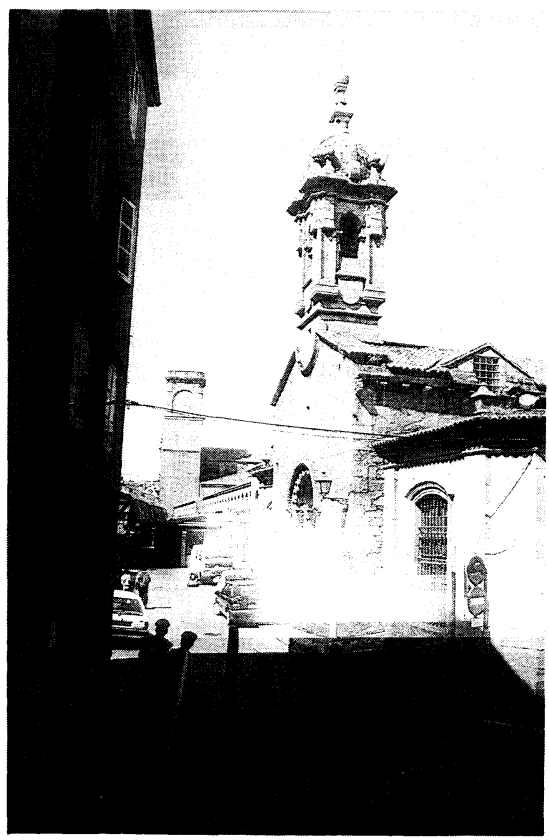

Fig. 11.- Vista actual de la calle del Mercado, entre las iglesias de S. Fiz de Solovio, en primer término, y la de S. Agustín, al fondo. barroco de la iglesia colindante de S. Fix, proyectada por el arquitecto Simón Rodríguez, y la portada románica de la misma, disiparían cualquier duda (Fig. 11) al visitante.

\section{- ¿Antecedentes tipológicos?}

¿Cabría encontrar algún parentesco tipológico, históricamente ya conocido, para este recreado conjunto de naves mercantiles?.

Si imaginamos cada nave sin el elemento caseta, es decir, sin los cierres frontales y laterales de que disponen, podríamos decir que estábamos ante un sorprendente conjunto seriado de ocho templos, de planta basilical romana de tres naves, carentes de ábsides y dispuestas contiguas y paralelas cada cuatro, en simetría con respecto a un atrio central. Éste, a su vez, podría disponer del correspondiente campanario, en la planta superior de su torreta central. Los testeros semiabiertos de igual forma a ambos frentes, comunican las naves con las calles exteriores y con el atrio interior.

Por otro lado, también la depurada solución constructiva de triple de ventanal, con arcos de medio punto en la parte superior de los muros testeros, nos aproxima al tipo de soluciones propias del templo o palacete prerrománico asturiano (14).

Se diría que los geniecillos del lugar, cansados tras setenta años de la presumible profanación ambiental que supuso el mercado decimonónico, tan ajeno a la arquitectura de la ciudad jacobea y entorno, se hubieran conjurado para inspirar, sutil y hábilmente a su autor y concebir sobre la misma traza decimonónica, la ambientación casi sacra del actual mercado; que por otro lado está situado entre las iglesias de S. Fiz de Solovio, al Sur y de S. Agustín, al Norte.

¿Pretendió J. Vaquero construir entre ambas el gran templo de Abastos que hoy es?. Nada nos dice al respecto la lucida exposición de motivos e intervenciones que Vaquero ha expresado en su emotiva carta.

\section{-¿Más elementos heredados?}

Además de la impronta de la traza definitiva, aportada por el mercado decimonónico al actual, que ha supuesto la ordenación de su planta, ¿existen o permanecen más elementos heredados que aun hoy día podamos apreciar?.

$\mathrm{Su}$ autor nos informa de que también le parecieron aprovechables, además de la red general de desagües, “...el pavimento general de losas de granito y el murallón sobre la calle Virgen de la Cerca...".

La segunda fotografia de la documentación gráfica citada en la nota 9, catalogada hacia 1925 y realizada en tiempo lluvioso, nos informa de cómo el espacio central con su 
fuente de agua potable, carecía del actual enlosado. Así pues, la actuación de Vaquero Palacios, prolonga la calidad decimonónica del enlosado de las naves interiores a los espacios exteriores ,central y posterior.

También la citada fotografía nos habla de la preexistencia de la balaustrada a la calle Virgen de la Cerca. Por diseños similares existentes en la ciudad, podría haber sido aportada a la terminación de la obra por el maestro de obras citado, que la construyó. Una consulta al Archivo Municipal de la ciudad resuelve la duda (15). En febrero de 1889, a seis años de funcionamiento del mercado, el grave hundimiento producido en una parte central del murallón a la Virgen de la Cerca, provoca que el entonces arquitecto municipal, Faustino Domínguez Coumes-Gay, redacte con urgencia el proyecto del alto murallón definitivo que hoy conocemos, en la parte central de todo su frente (Fig. 12). Argumentando que aquel lugar ya no podría tratarse como un muro de camino, lo eleva al mismo nivel de la planta del mercado y lo dota, con frente a la calle Virgen de la Cerca, de su actual tratamiento y con balaustrada ornamental.

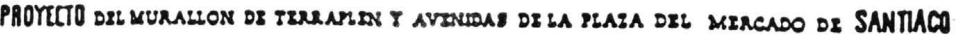

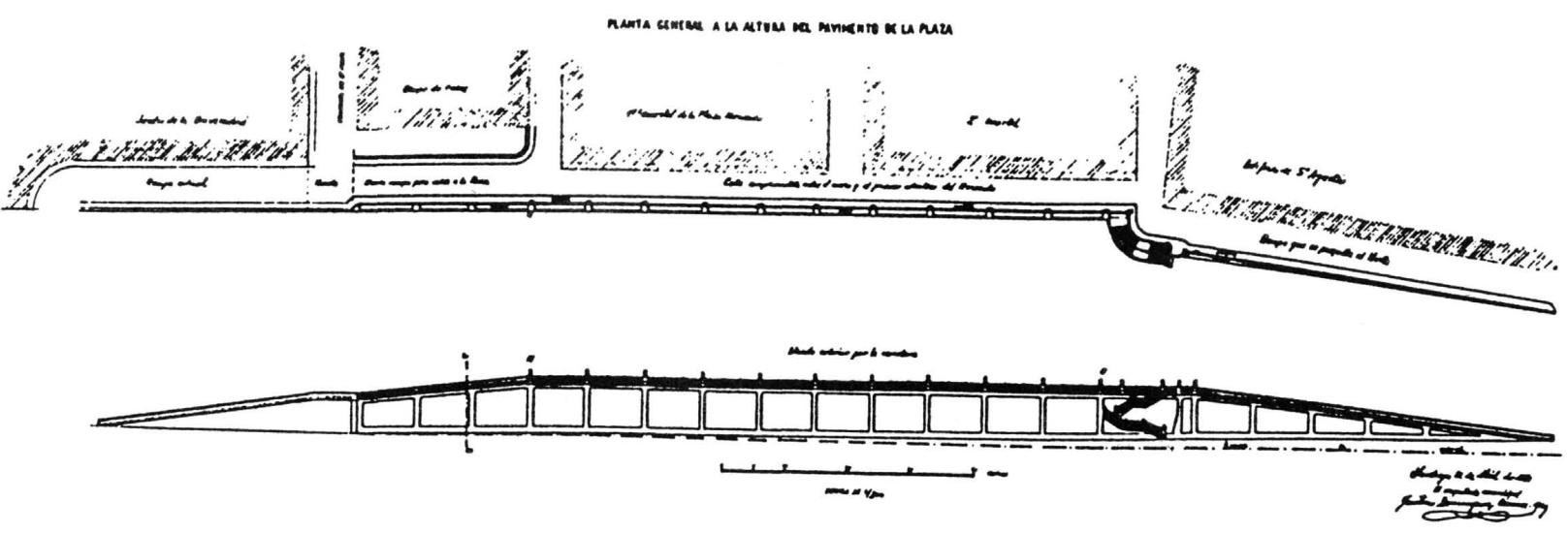

\section{INIDAS DI LA PLAZA DII MIRCADO DI SANTIACO}

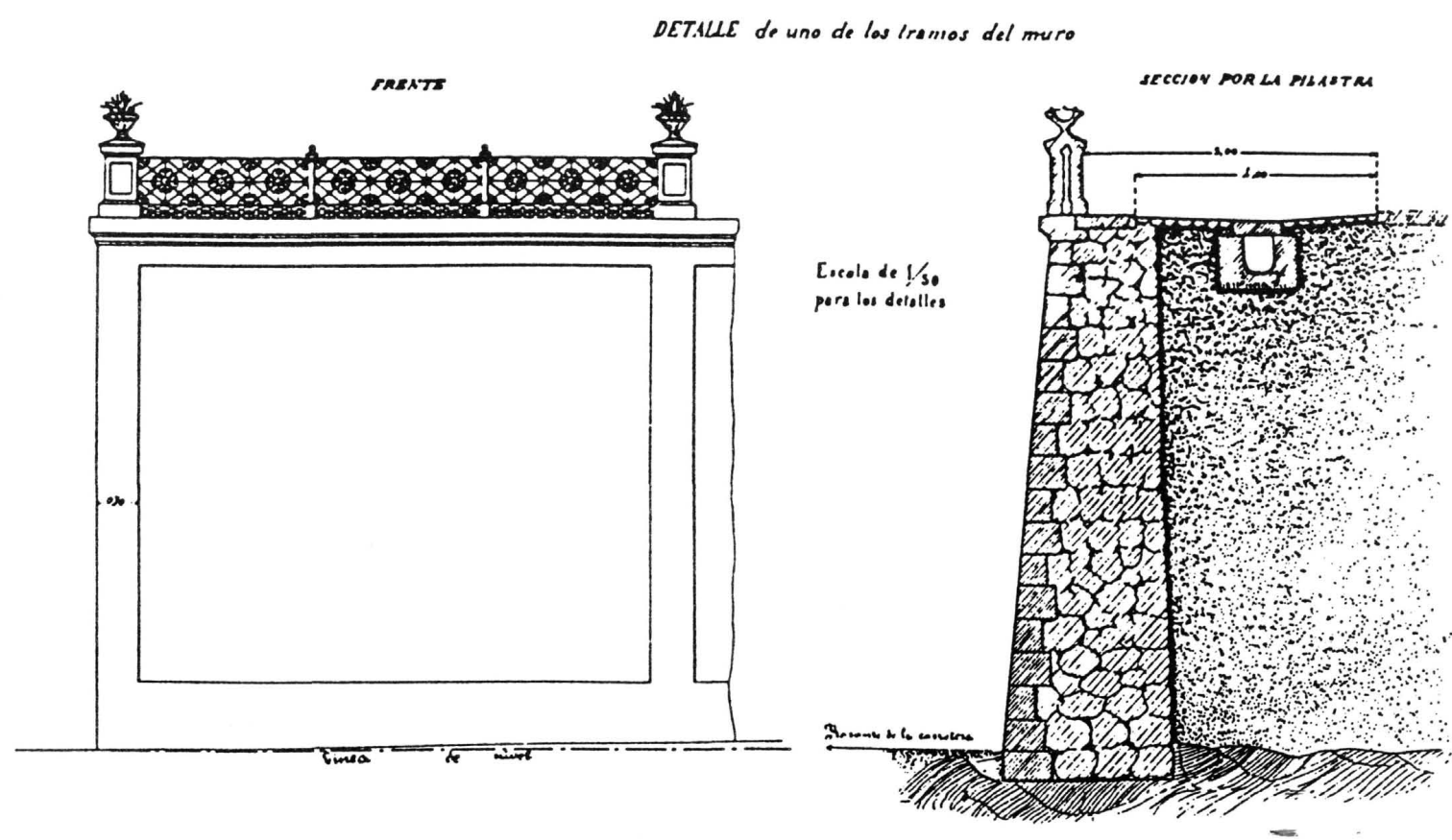

Fig. 12.- Planos del proyecto del murallón de la plaza del Mercado de Abastos con frente a la avenida Virgen de la Cerca, redactado por Faustino Dominguez Coumes-Gay (a. m.) en 1889. 


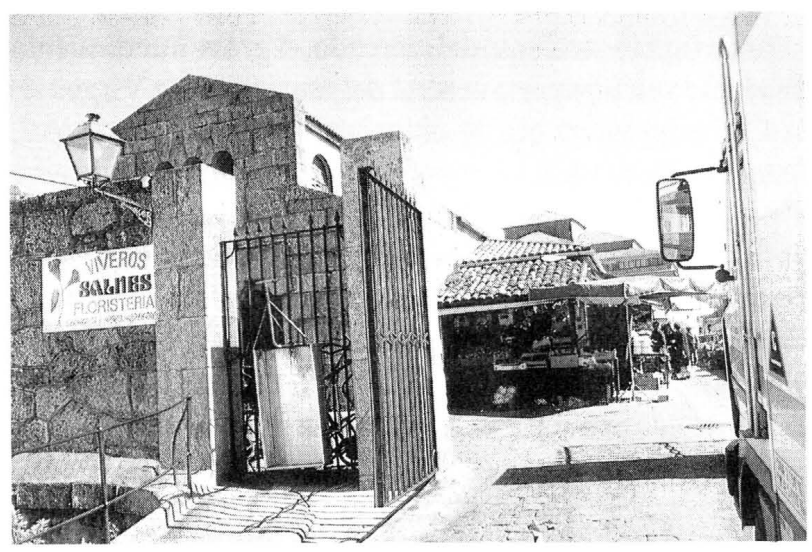

Fig. 13.- Rejería precedente.

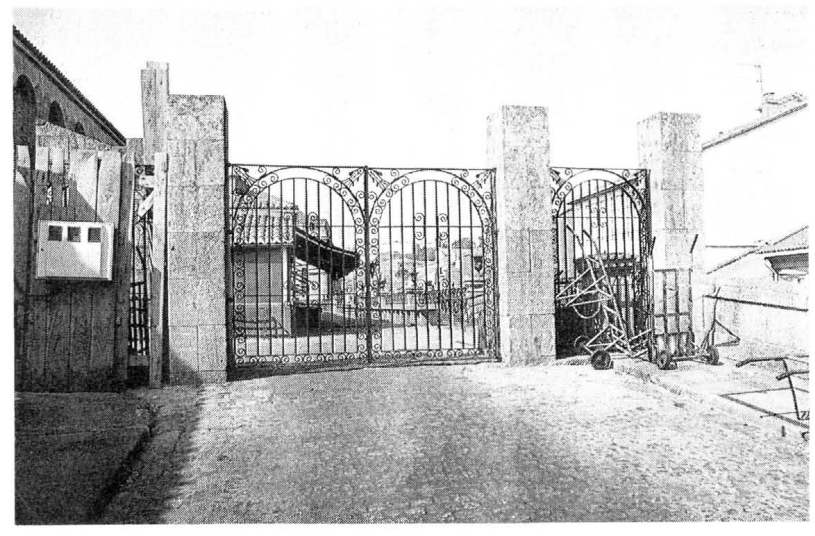

Fig. 14.- Rejería rehabilitada.

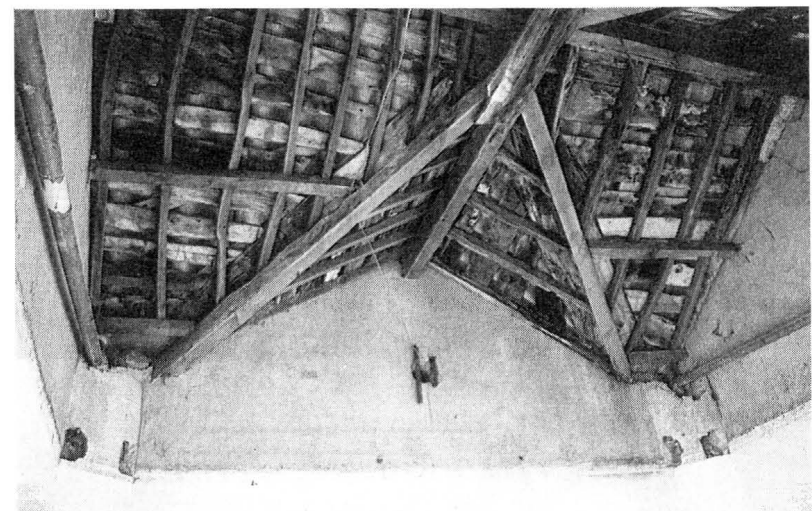

Fig. 15.- Entramado de la cubierta, ocultado por el falso techo precedente

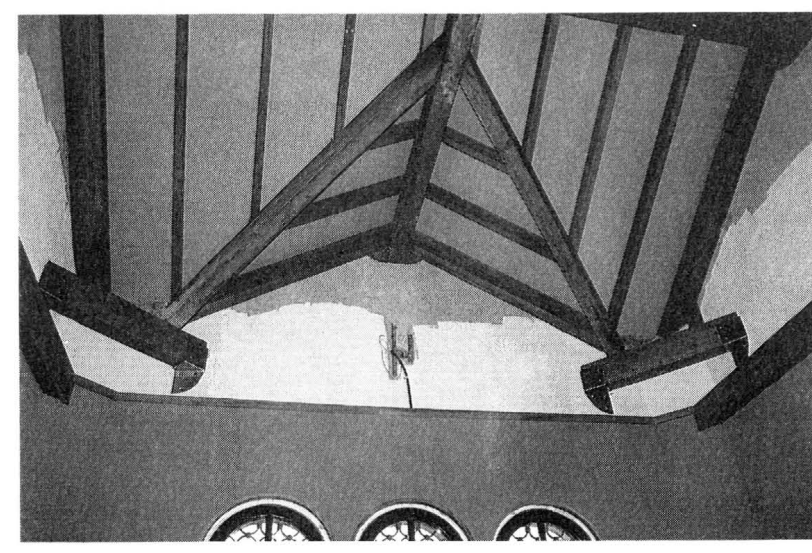

Fig. 16.- Entramado de cubierta visto, rehabilitado.

(c) Consejo Superior de Investigaciones Científicas Licencia Creative Commons 3.0 España (by-nc)

\section{II. - Las obras de rehabilitación}

II -1.-No se trata de obras de creación de nuevos espacios, sino de actuaciones sobre los locales y naves existentes, con diversos niveles de intervención

1.-Redistribución de los locales de aseos públicos y anexo, con frente a la calle Virgen de la Cerca.

2.-Renovación de las estructuras horizontales de la torreta central, con su nueva disposición de usos.

3.-Reposición de las ventanas laterales de las bóvedas y nuevo pintado de su techo.

4.-Dotación de una nueva red de alumbrado y megafonía en las naves, anulando la deficiente instalación precedente

5.-Dotación de un sistema séptico, de recogida de aguas superficiales, en todo el mercado, con acometida desde cada caseta.

\section{6.-Reposición de la cerrajería de taller.}

\section{Criterios seguidos:}

Como criterio general, se ha respetado y tratado de potenciar los valores constructivos de la arquitectura de Vaquero Palacios desde tres líneas de actuación, que pueden resumirse en las acciones de reposición, sacar a la luz los detalles ocultos y dialogar en los nuevos.

En primer lugar, la más directa e inmediata: reponer en su propio modelo y material aquellos elementos ya deteriorados que piden su renovación: carpintería de exterior de las naves y rejería de cierre del mercado. Puntualmente, donde el modelo preexistente nada tenía que ver con el original, por haberse procedido al cierre en época posterior a su construcción, se ha tratado de imitar la rejería original (Figs. 13 y 14).

En segundo lugar, otra también directa, que ha consistido en dejar vistos en toda su expresión y función detalles constructivos ya existentes y parcialmente tapados por el tablero del falso techo precedente. Son éstos los 8 canzorros ortogonales de la planta $1^{\mathrm{a}}$, de la torreta, o también el entramado oculto, tras el falso techo de la cubierta, en la planta superior (Figs. 15 y 16).

Esta reposición de los entramados horizontales de la torreta, donde un solado tipo sandwich, formado por tablero aglomerado hidrófugo en su cara inferior, de 20 $\mathrm{mm}$, láminas de aislamiento térmico Floormate de $5 \mathrm{~cm}$ y entarimado de Elondo, ha venido a sustituir el entarimado y falso techo precedente, trae la expresion vistadel entramado horizontal, con vigas de madera laminada y pontones de madera serrada, tratadas con Xilamón fondo y Xiladecor. 
Como se puede deducir de lo expuesto, no se ha efectuado un trabajo de restauración. El entramado de la planta primera, donde se alojan dos pequeños locales: despacho del veterinario y guarda de la plaza, frente al local único precedente, ha sido reinterpretado. Partiendo de la posición ortogonal de canzorro existentes en los cuatro lados, se han dispuesto vigas en cruz (Figs. 17 y 18).

Cabe mencionar cómo su distribución, según ejes de vigas cruzadas y el tratamiento superior acristalado de su tabiquería de Pladur, permiten la vista integral del entramado visto, dando mayor amplitud visual a los propios espacios (Fig. 19).

Distintas piezas auxiliares de acero inoxidable (Fig. 20), adaptadas a sus funciones de sujeción y apoyo, han sustituido el sistema tradicional de armar y trabar directamente las vigas y pontones y el apoyo directo en muros exteriores. En el primer caso, se evita disminuir la sección portante de la viga y, en el segundo, quedan aisladas las vigas de la humedad que el muro exterior pudiera trasmitirles.
Este criterio, mantenido en las soluciones de esquina del entramado de la cubierta, ha llevado a introducir un elemento auxiliar tipo durmiente, que, colocado ortogonalmente a las bisectrices de la planta cuadrada de la torre, absorbe los apoyos del entramado original, introducido por Vaquero, para dar respuesta a sus limahoyas desplazadas. Éstas permiten diferenciar los testeros Este y Oeste, donde se sitúan las esferas del reloj, de los del Norte y Sur, tratado convencionalmente con aleros salientes en toda su amplitud.

El local superior ha sido dedicado a la oficina del encargado municipal del Mercado. Paneles de poliestireno obstruido Wallmate de $5 \mathrm{~cm}$ y revestido de corcho, han dado respuesta a las condiciones de aislamiento térmico. Para un cierre adecuado entre la carpintería y la piedra, ha sido necesario colocar juntas elásticas de neopreno, que impiden la ventilación permanente e involuntaria de un local tan acristalado.

Por último, la tercera línea de actuación: la aportación de
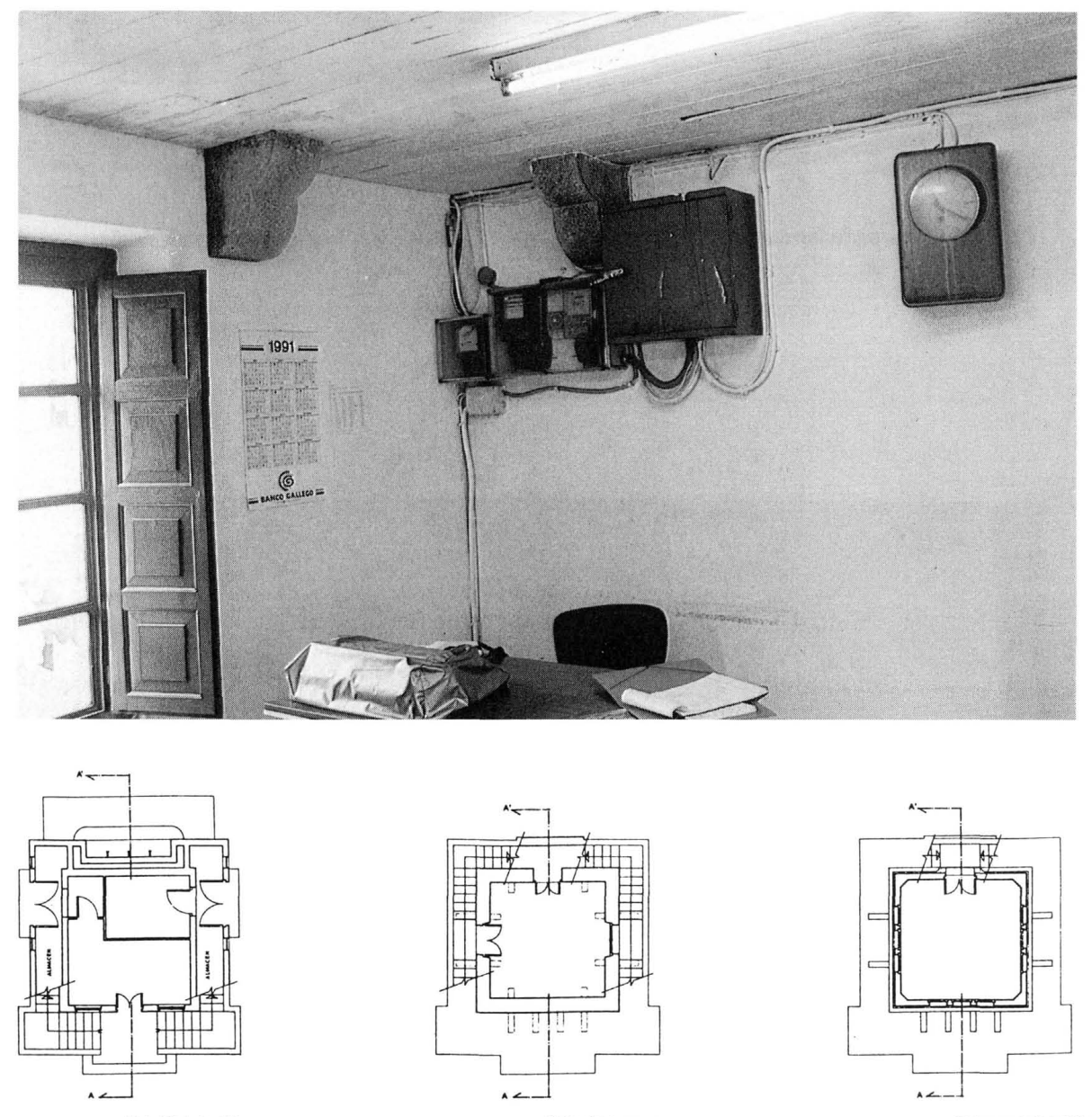

Fig. 17.- Falso techo preexistente en la planta primera. Plantas s/ estado precedente. 

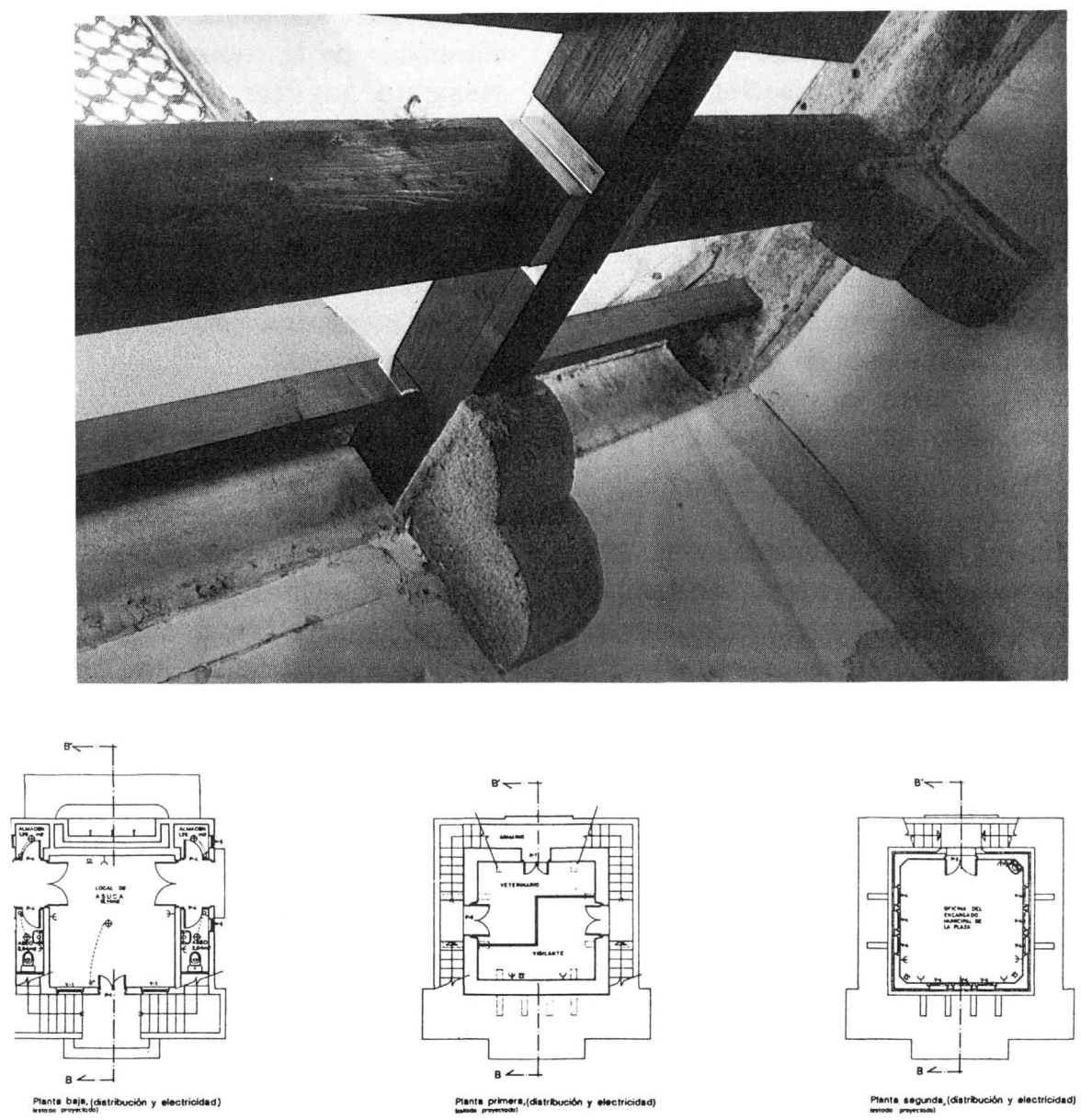

Fig. 18.- Entramado horizontal rehabilitado, en fase de obras. Plantas s/ estado rehabilitado.

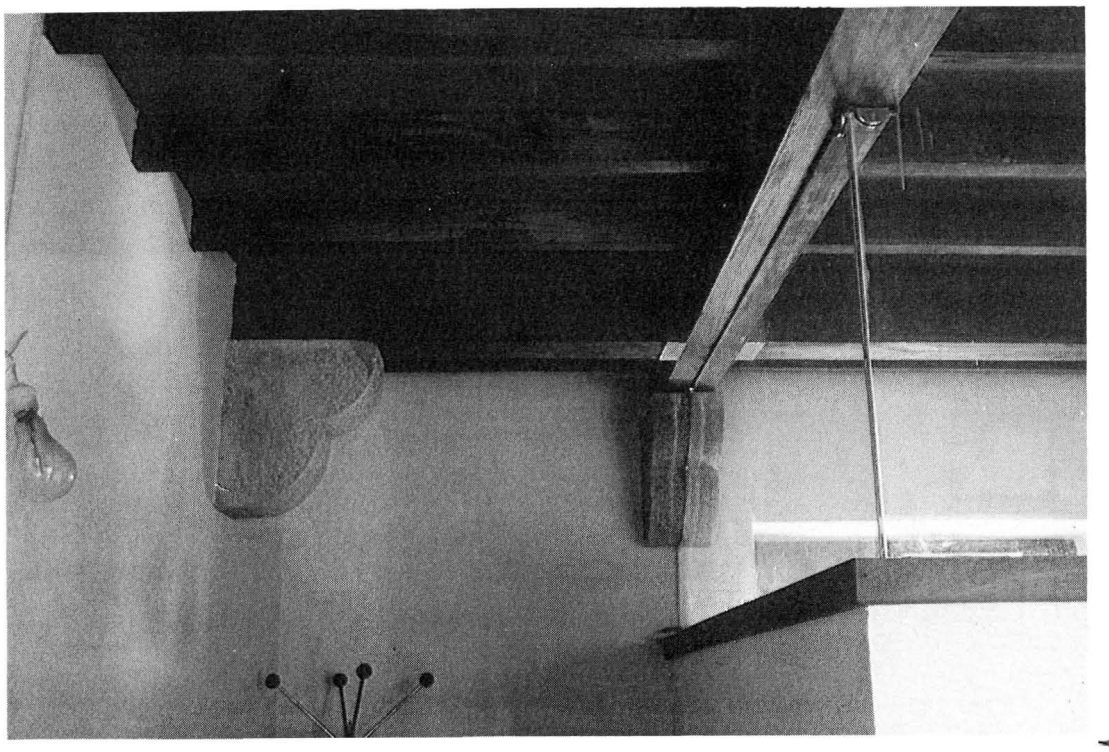

Fig. 19.- Entramado horizontal y tabiquería divisoria rehabilitados.

(c) Consejo Superior de Investigaciones Científicas 

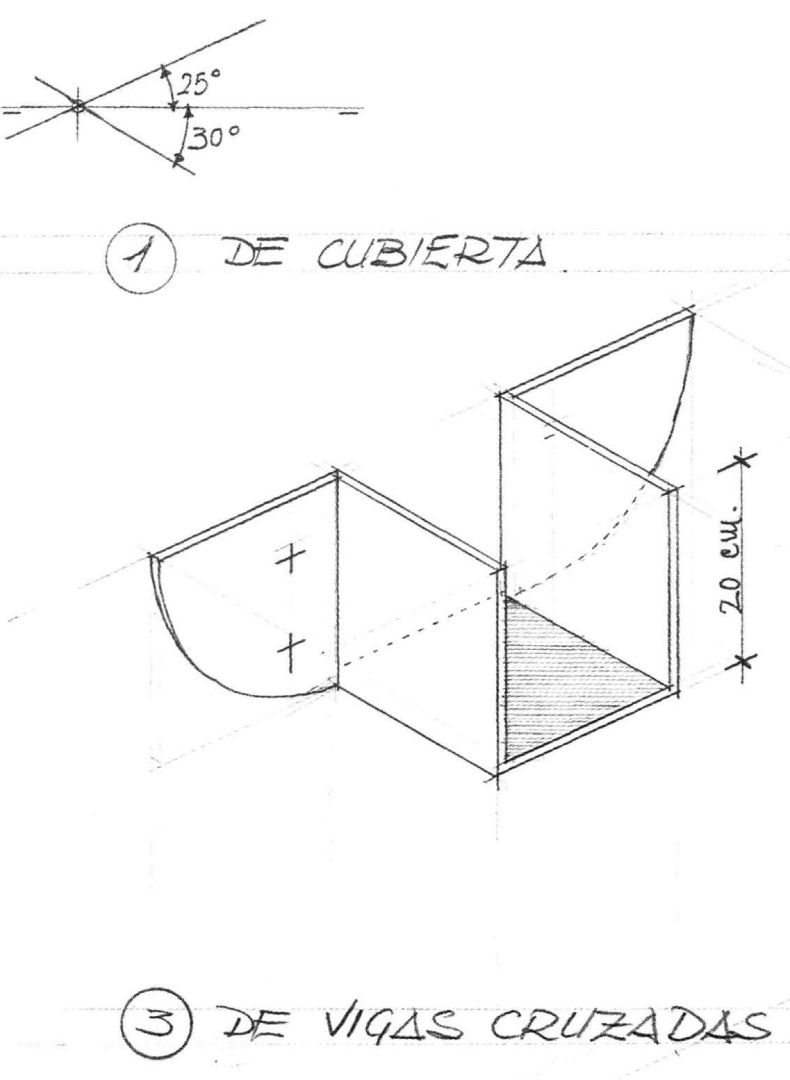

\section{DE VIGAS CRLIZADAS}

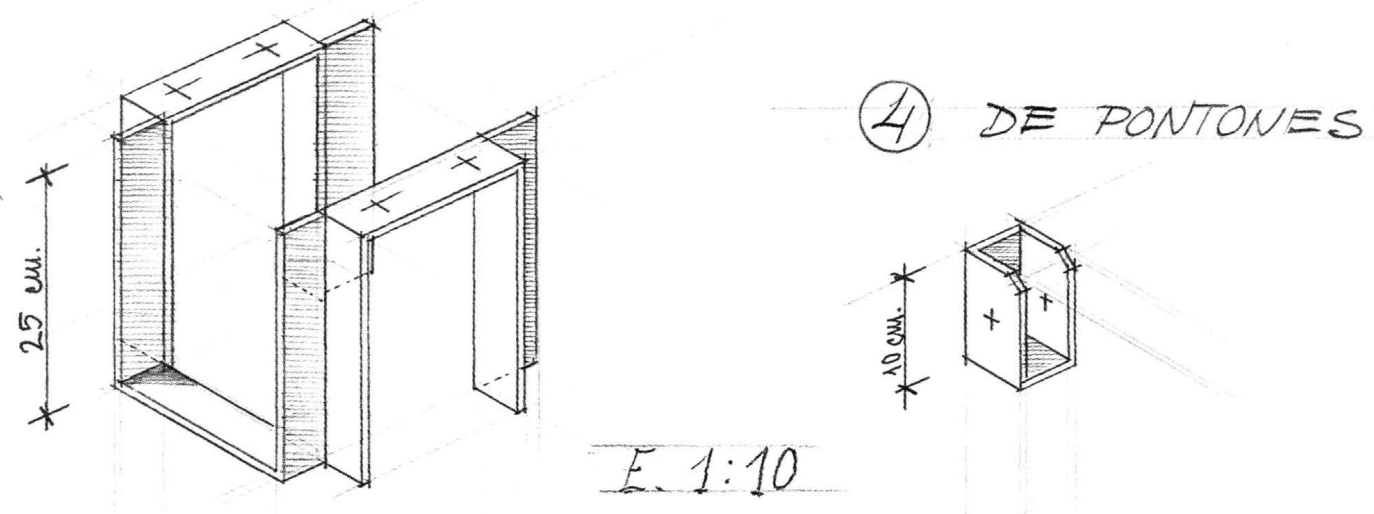

Fig. 20.- Elementos metálicos auxiliares de sujeción y apoyo de acero inoxidable utilizados.

ciertos detalles constructivos ajenos a los preexistentes, también se apoya y pretende enfatizar la arquitectura preexistente, desde sus propias funciones y situación.

Cabe citar, en primer lugar, cómo el detalle constructivo de la pieza que, a modo de albardilla, remata la tabiquería interior de los aseos, proviene de la prolongación de la imposta de remate del propio muro exterior, del ventanal abierto de los aseos públicos (Figs. 21, 22 y 23).

En segundo lugar, hay que mencionar, cómo la red de desagüe del mercado decimonónico, reutilizada por Vaquero en los cuarenta, vuelve hoy a poder ser otravez reutilizada, admitiendo su conversión en canal séptico en todo el ámbito del Mercado. Hay que decir que éste era uno de los (c) Consejo Superior de Investigaciones Científicas Licencia Creative Commons 3.0 España (by-nc) problemas más urgentes a solucionar: los malos olores en épocas calurosas se percibían en un mercado como éste, a pesar del lavado diario de su suelo y canal de desagüe precedente. La dotación de sumideros sifónicos a cada caseta, con red de desagüe conectada al hoy canal, también séptico, dotado de las arquetas diseñadas al efecto, adaptadas en su altura y superficie a las del canal y a la forma curvada de la pavimentación precedente, incluso con sus encuentros en cruz, en los espacios exteriores a las naves, ha solucionado el tema (Fig. 24) (16).

Laeconomía de la obra no ha permitido renovar el pavimento en las zonas externas a las naves. Los ägujeros anteriores han sido taponados con material de resinas. ¿Por qué preexistían agujeros y amplios sumideros?. Se piensa que, 

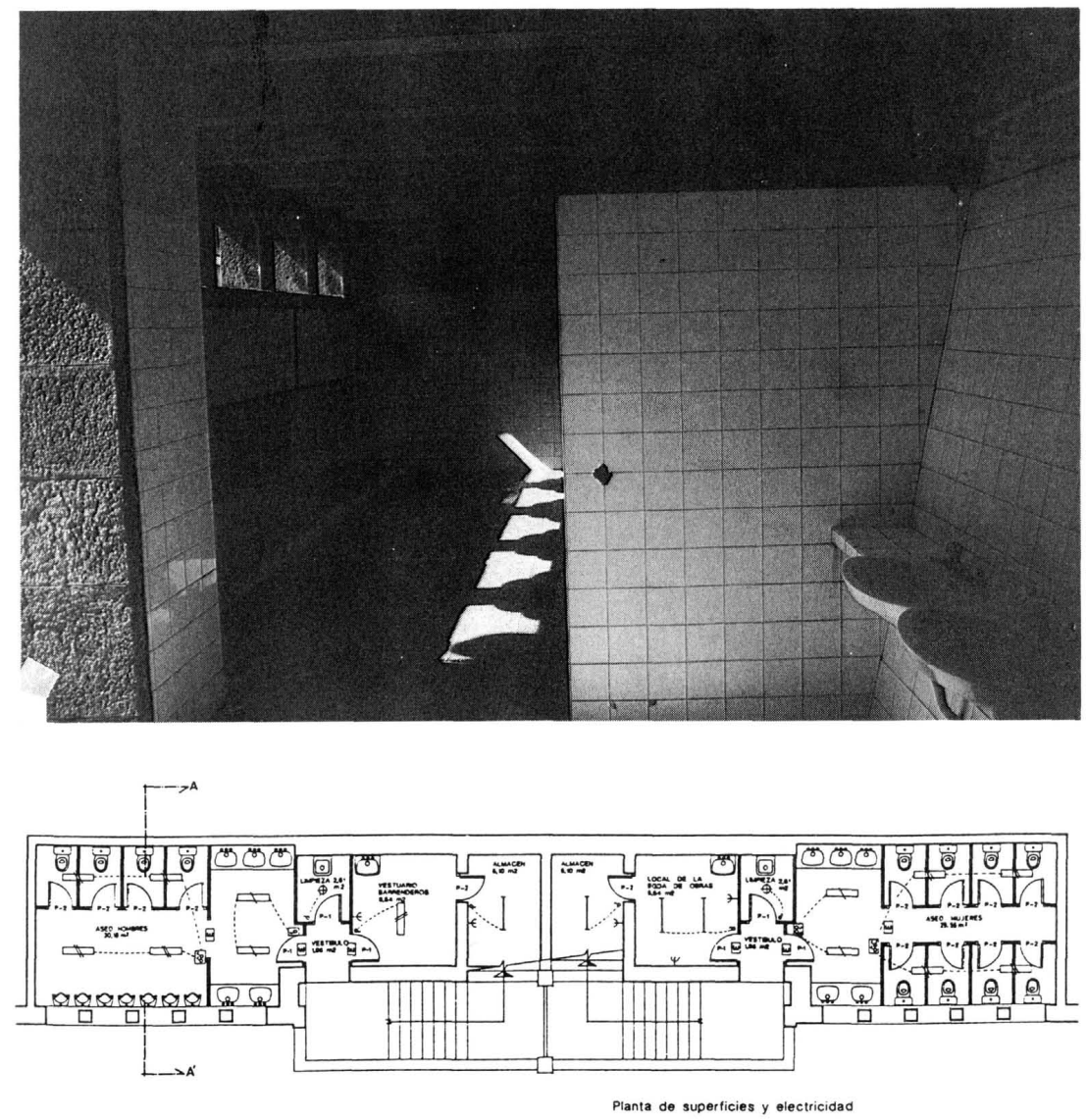

Fig. 21.- Estado precedente de aseos. Planta rehabilitada.

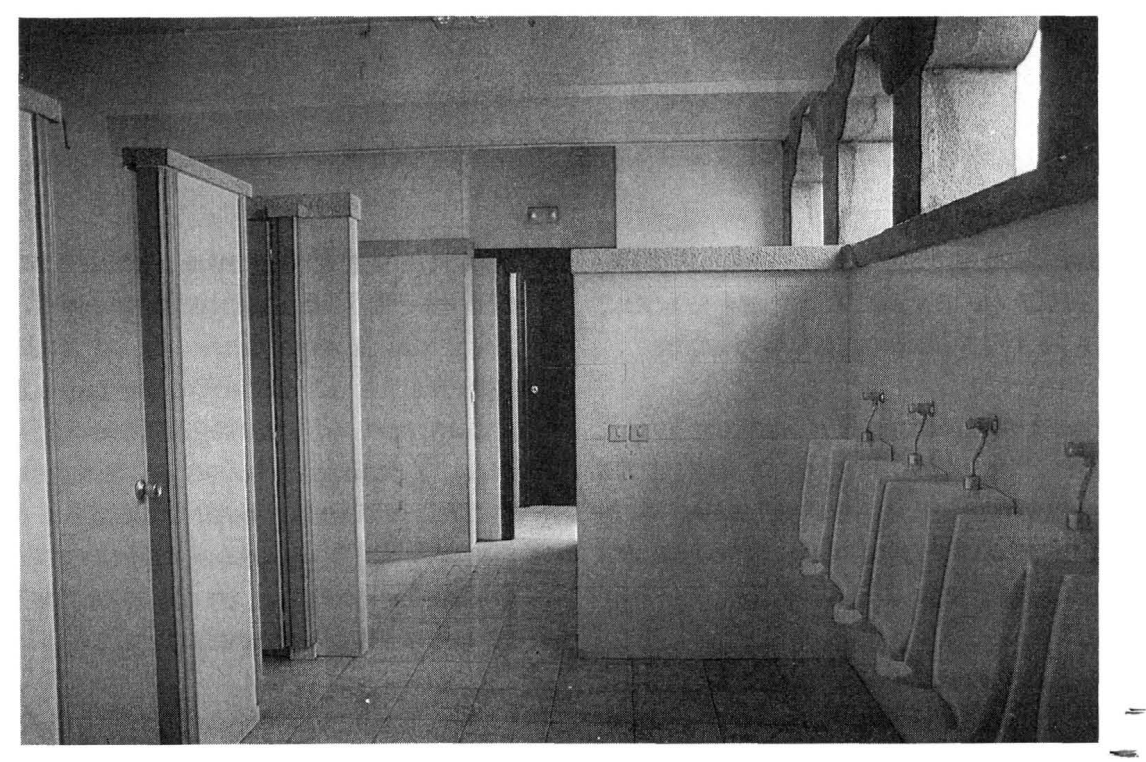

Fig. 22.- Estado rehabilitado. Albardilla en remate superior de tabiquería divisoria, en continuidad con la imposta del muro exterior. 


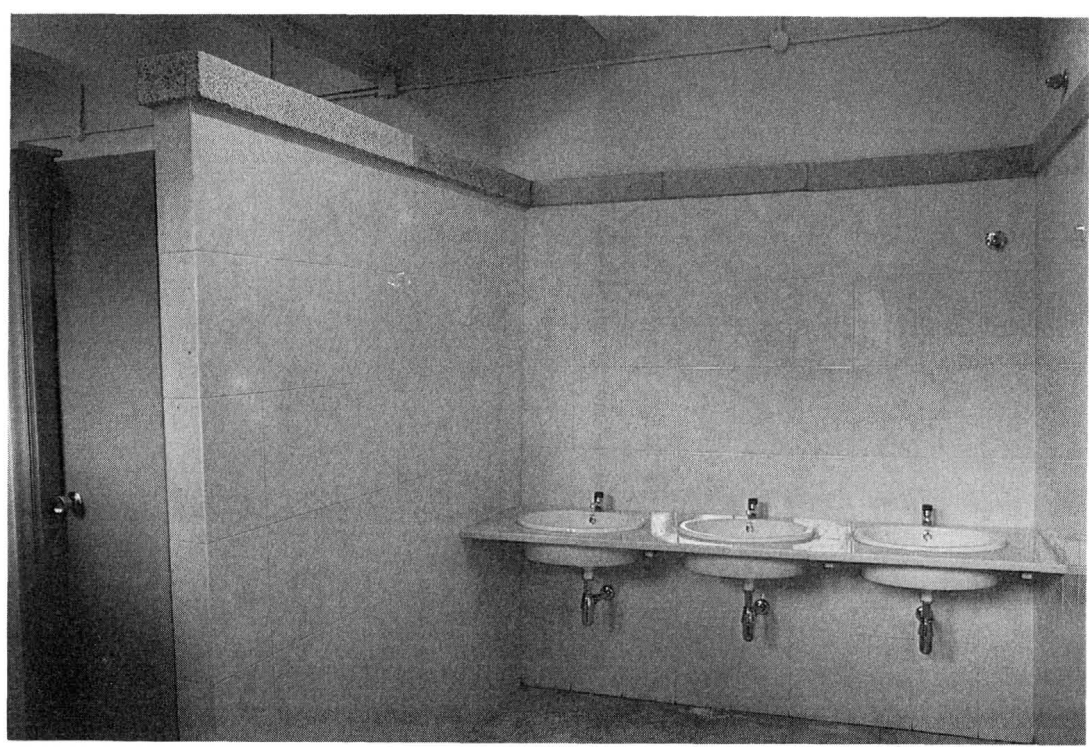

Fig. 23.- Otra vista de lo anterior.

inicialmente, el mercado dispuso sólo de canal de piedras geométricamente horadadas y que, posteriormente, quizás ante la falta de drenaje y en la necesidad de limpiar la red, no solamente de aguas superficiales, sino de todos los desechos que terminaban en el mismo, fue necesario dotarlo de los sumideros de rejas, hoy día sustituidos por las arquetas actuales, cuyos pequeños orificios no permiten la evacuación de restos de alimentos desechados.

Un tercer tema se refiere a la dotación de nuevo alumbrado y megafonía, en sustitución de los deficientemente existentes en las naves. La iluminación anterior negaba el efecto abovedado; la actual enfatiza su efecto, como puede observarse (Fig. 25).

La eliminación de cableados y tendidos eléctricos, forma parte de una segunda fase de obras. La situación de un canal de acero inoxidable de sección cuadrangular, debidamente colgado de la bóveda mediante elementos del mismo material, diseñado al efecto, ha permitido, a la vez ocultar el cableado correspondiente, dotar además a las naves de luz directa y megafonía colgada; prever la conveniente luz indirecta ambiental que permite el diálogo visual con el propio espacio abovedado iluminado, y actuar simultáneamente como luz nocturna y de seguridad.

Aun resueltos con eficacia el alumbrado y megafonía, podría ser criticable el impacto ambiental que estos elementos puntuales producen.
Parece ser que un sistema alternativo lineal integrado, que se pensó como idóneo con las exigencias que requieren el colocado: nivel de rendimiento y economía, doble iluminación, estanqueidad y megafonía para el espacio exterior que son las naves, no se daba fácilmente en el mercado.

\section{Ejecución de las obras}

Con el fin de no interrumpir el funcionamiento diario y matinal del Mercado, las obras realizadas por la empresa local NEORSA, de 1992 a 1993 fueron ejecutadas en jornadas de tarde, a partir de las 14 horas.

Este necesario e ininterrumpido funcionamiento, obligó a llevar las obras de forma coordinada (Fig. 26). Cada día había que dejar libres y fuera de peligros la circulación matinal por las naves. Para la colocación de la carpintería de las bóvedas y su pintado, el encargado de obra de la empresa ideó el tipo de andamio que aparece en la figura 27 , y que permitió la circulación citada.

\section{II - 2.-Los expositores de las casetas}

Es este otro tema, referido a la fachada de las casetas y su adaptación a las actuales necesidades comerciales de expositores en sus distintos usos: expositores frigoríficos para carnes, bandejas expositoras con īnstalación de frío para pescados y bandejas alternativas $\overline{s i n}$ instalación de frío. 

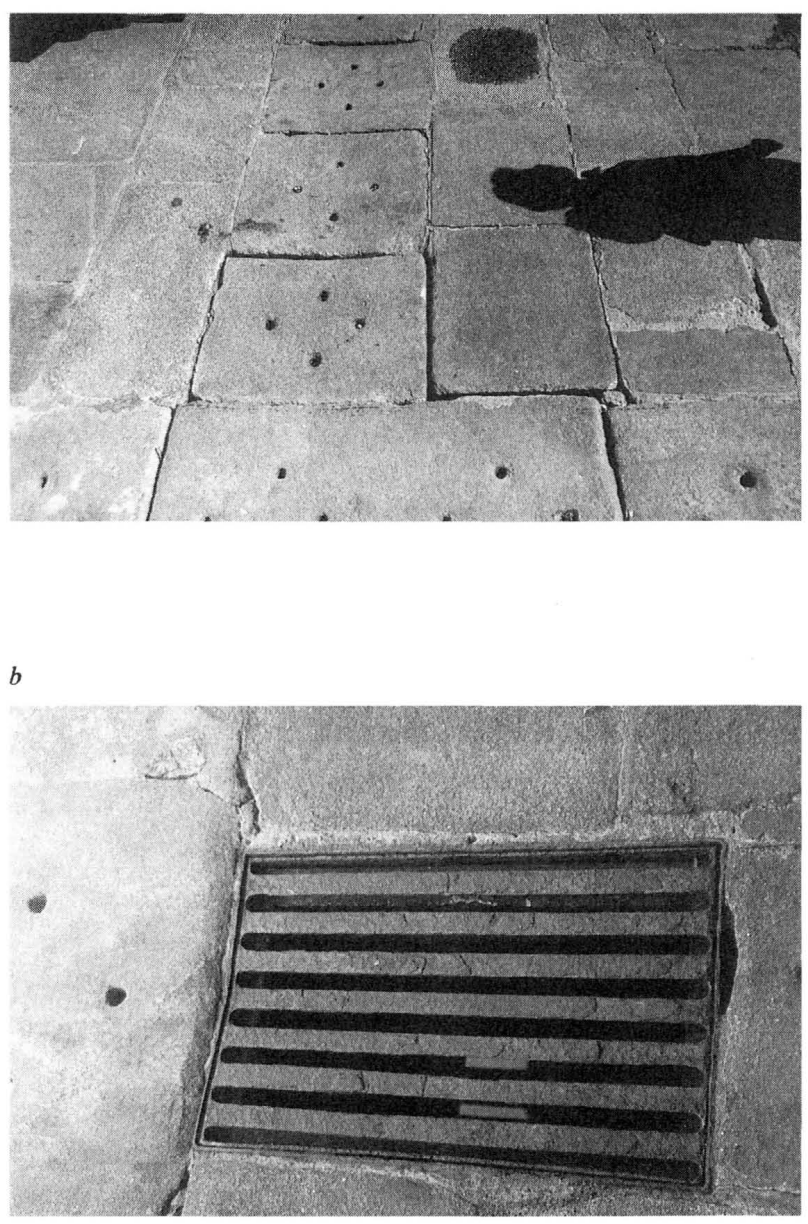

$a$

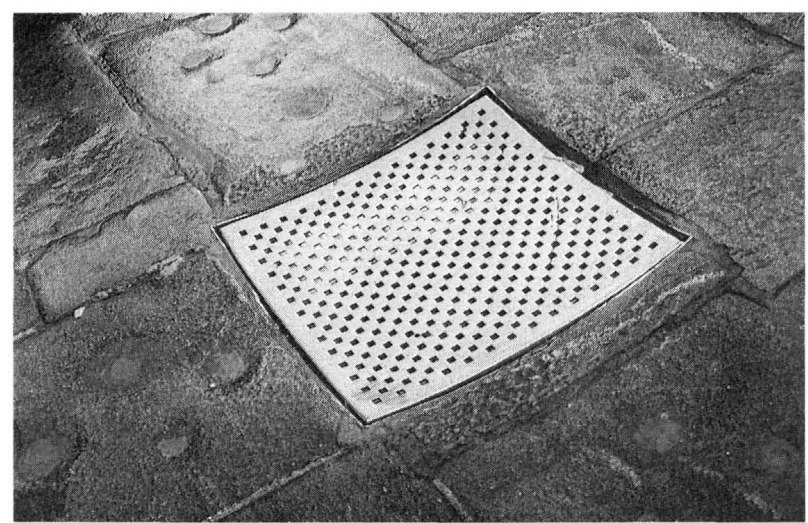

$b$

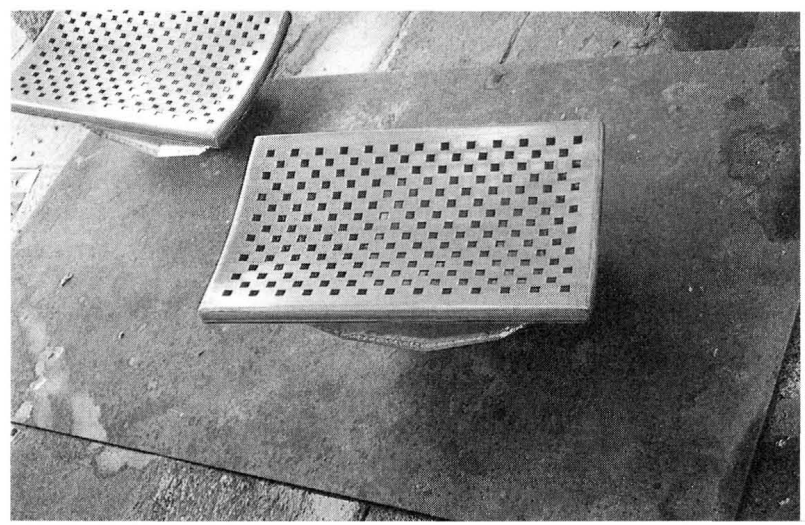

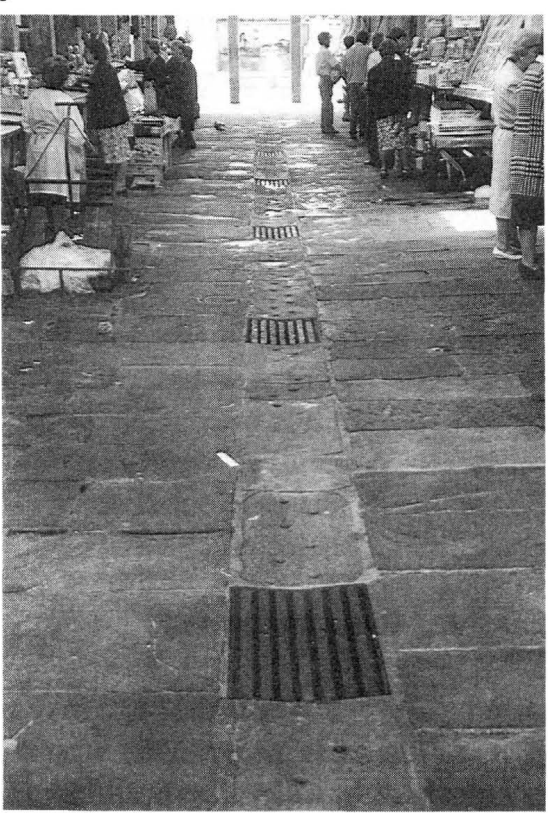

Estado precedente.

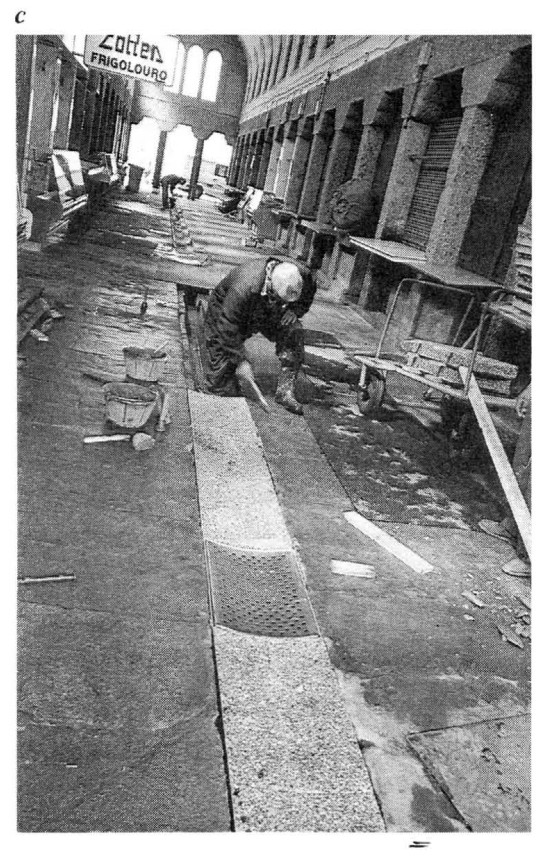

Estado rehabilitado

Fig. 24.- Canal de desagüe.

(c) Consejo Superior de Investigaciones Científicas 

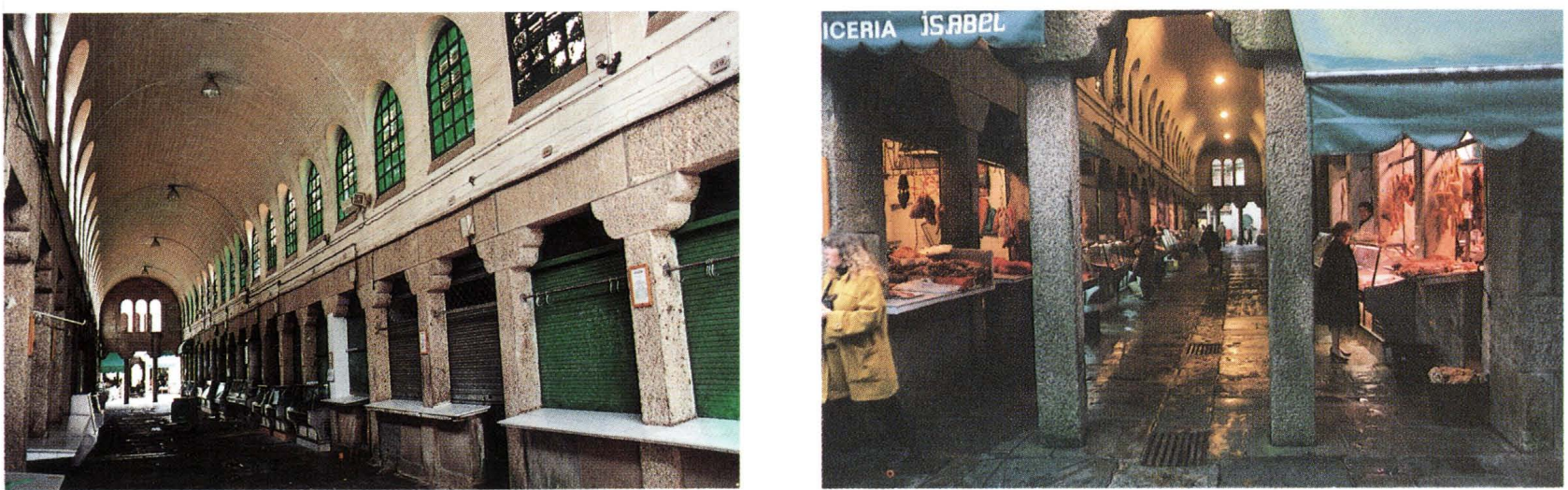

Iluminación precedente: diurna y nocturna.
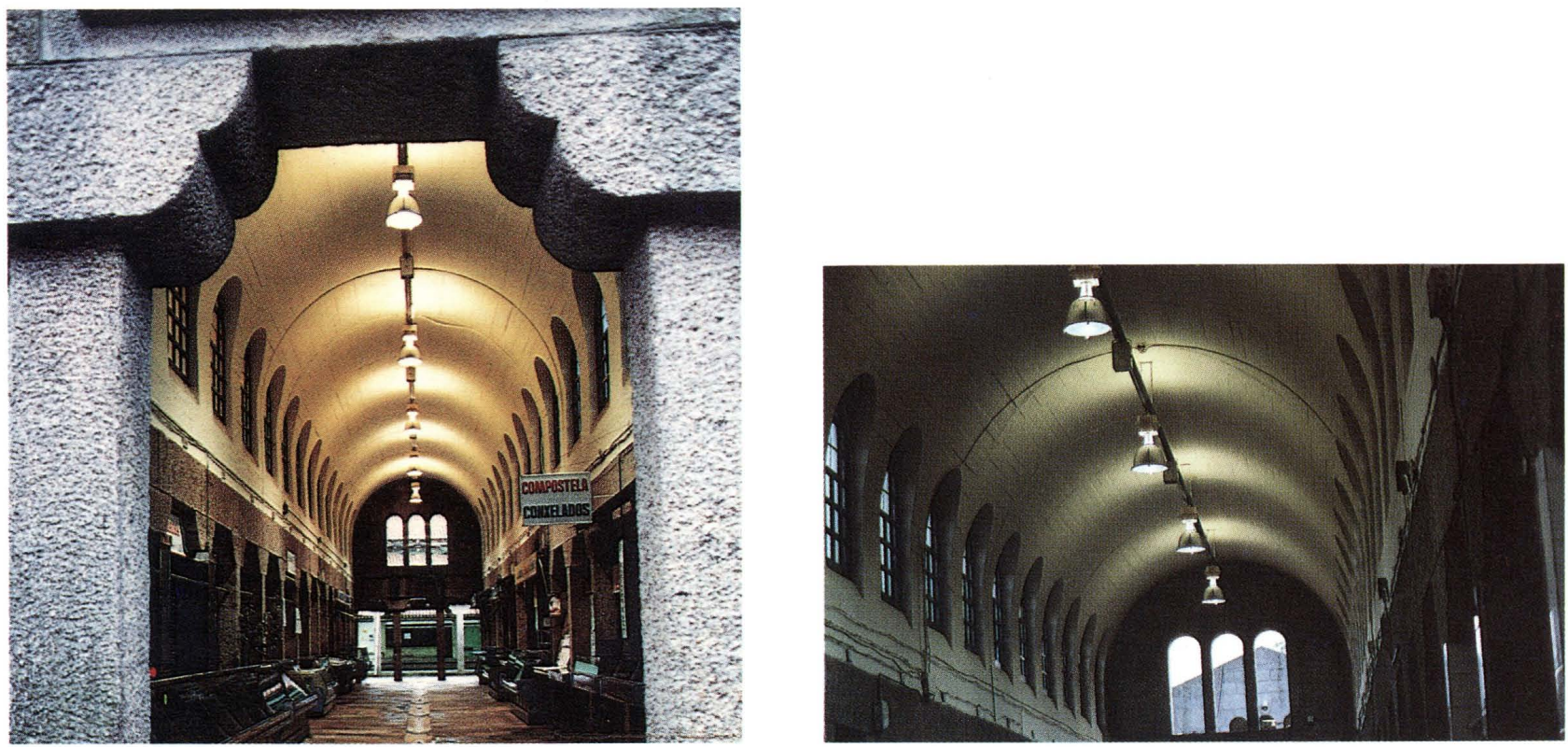

Iluminación rehabilitada.

Fig. 25

$\mathrm{Si}$, según hemos visto, la arquitectura global del Mercado ha mantenido básicamente su carácter original, no ha sucedido lo mismo con las fachadas interiores de las casetas, en las naves. Es aquí, donde el atentado al patrimonio construido de origen, ha experimentado su mayor agresividad. De las 333 unidades de que disponen las naves, tan sólo una veintena mantienen hoy el diseño de puerta mostrador de madera de Vaquero Palacios (Fig. 28). La falta de un criterio establecido y coordinado, que hubiera previsto la adaptación de los frentes de casetas a la de expositores frigoríficos de carne, o la de bandejasexpositores de pescados y mariscos, ha producido su actual y agresivo aspecto, mostrado, a título anecdótico, en las figuras 29 y 30 . Coexisten más de 15 modelos distintos de ambos expositores, unos 12 carteles anunciadores de diferente entidad y unas 6 calidades de revestimientos de pilares. Aceroinoxidable, alicatados, plaquetas, mármoles, hacen este papel. Paralelamente, la libre asignación de casetas a un solo usuario o firma comercial, permitida hasta esta actuación, ha colmado la amplitud de los frentes agredidos. Prácticamente, una de las naves, se encuentra desfigurada en la mayor parte de sus frentes.

No obstante, y pese al panorama expuesto, ya se ha detenido este crítico proceso de deterioro. La propia Asociación de usuarios de casetas, ASUCA, a laque notodos pertenecen, ha promovido un proyecto coordinado de actuación para los frentes de caseta. Dos unidades de caseta es el frente máximo establecido, que podrá mostrarse exteriormente unido. Las alternativas posibles de que un mismo usuario disponga de 1, 2 ó 3 unidades, se han expresado en el proyecto tipo (Fig. 31). La altura mínima con respecto al pavimento, de $70 \mathrm{~cm}$, y el vuelo máximo de expositores, de $0,50 \mathrm{~m}$, son los parámetros reguladores de los nuevos 


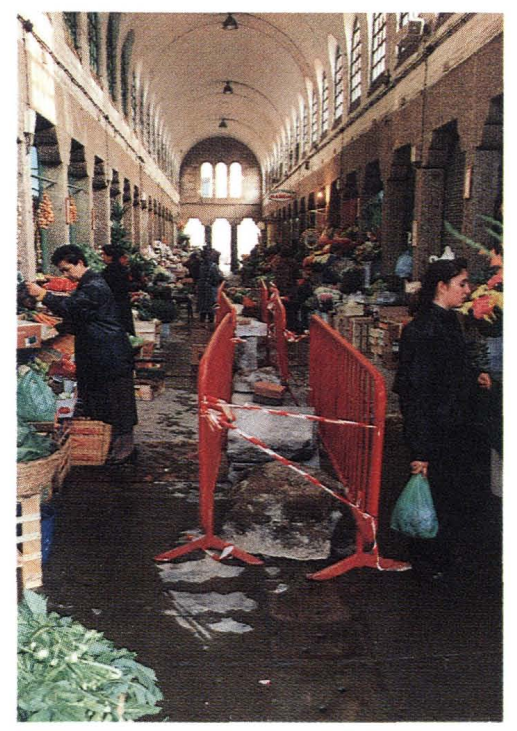

Fig. 26.- Ejecución de las obras: actividad de mañana.

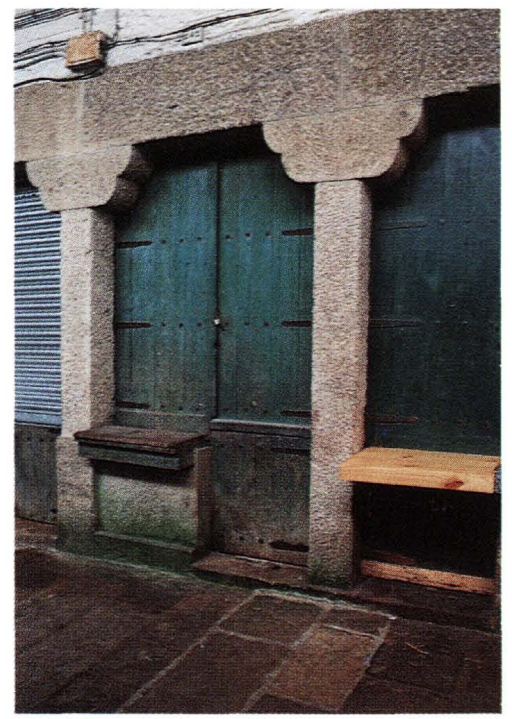

Fig. 28.- Cierre original de casetas de madera.

$0,50 \mathrm{~m}$, son los parámetros reguladores de los nuevos expositores. Estos parámetros han permitido, en algunos casos, recuperar el frente inferior inicial perdido y, en otros, mantenerlo.

Dos tipos de expositores-frigoríficos para carnes y frutas han surgido de las propias condiciones del Mercado. El tipo I, de acero inoxidable y vidrio, retoma la forma más común existente de las actuales, tipo mostrador o tipo caja, y reduce al máximo la exposición de la caja soporte (Figs. 33 y 34). El tipo II, lacado en verde y cerrado con superficie curva de metacrilato, proviene de la demanda de un usuario que ya los ha utilizado así en otra de sus tiendas de la ciudad. Al cumplir con los parámetros reguladores citados, se admitió

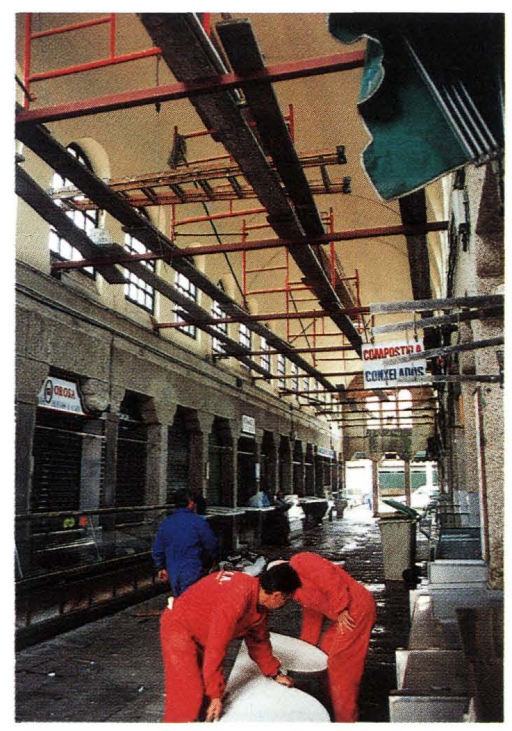

Fig. 27.- Andamio para tratamiento de bóvedas y renovación de la carpintería: actividad de tarde.

como tipo alternativo (Fig. 32)

También se han establecido dos tipos de bandejasexpositores, para pescados y mariscos, con instalación de frío o sin ella. Las primeras necesariamente de acero inoxidable (Fig. 35), y las segundas terminadas en granito silvestre "morena", coincidente con el granito de la plaza (Figs. 36 y 37).

Por otrolado, y basadoen algunos de los modelos existentes de cartel, se ha diseñado uno más acorde con las formas arquitectónicas (Fig. 33). Se ha previsto que los colores azul, rojo y verde respondan a los distintos productos de abastos: pescados y mariscos, carnes y frutas y verduras, respectivamente.

La renovación, ya iniciada de expositores en 30 unidades, permitirá invertir en su día el proceso de deterioro citado.

\section{II - 3.- Obras para una segunda fase}

Las obras citadas han supuesto una primera fase en la rehabilitación del Mercado. Bajo las actuaciones promovidas por el Consorcio de la ciudad y otras administraciones, se prevén las siguientes obras de mejora de imagen:

\section{- Limpieza de piedra en las naves}

- Retirada del cableado, con centralización de contadores

- Supresión de toldos a la calle del mercado, con dotación de puerta abatible

\section{- Cubrir el espacio central precedente}

- Dotación de bajantes y canalones de cobre 

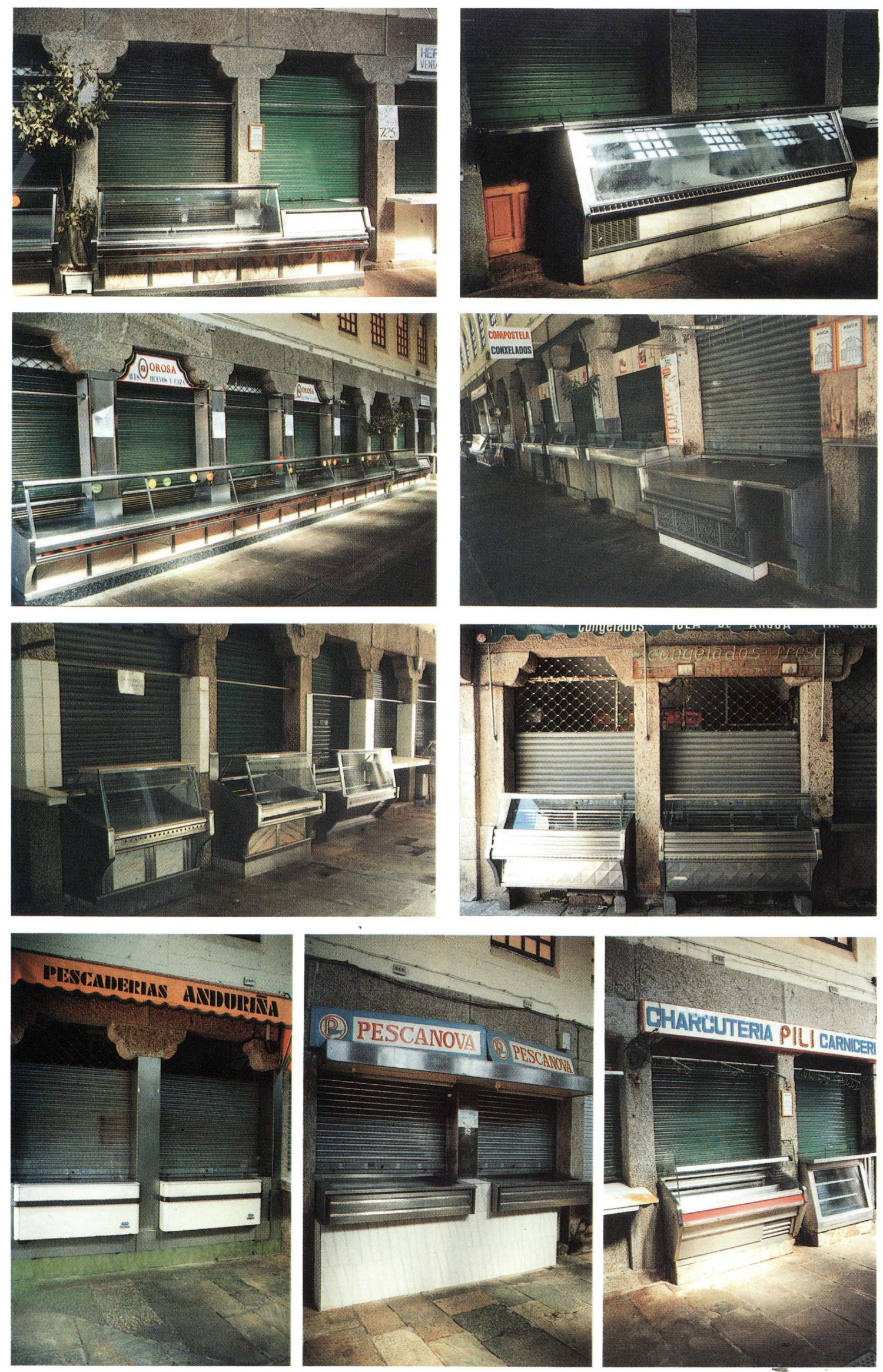

Fig. 29.- Algarabía de diversos mostradores de expositores-frigorificos, tipo mostrador; de carteles y de revestimientos de pilares, ajenos al hecho arquitectónico.

(c) Consejo Superior de Investigaciones Científicas 

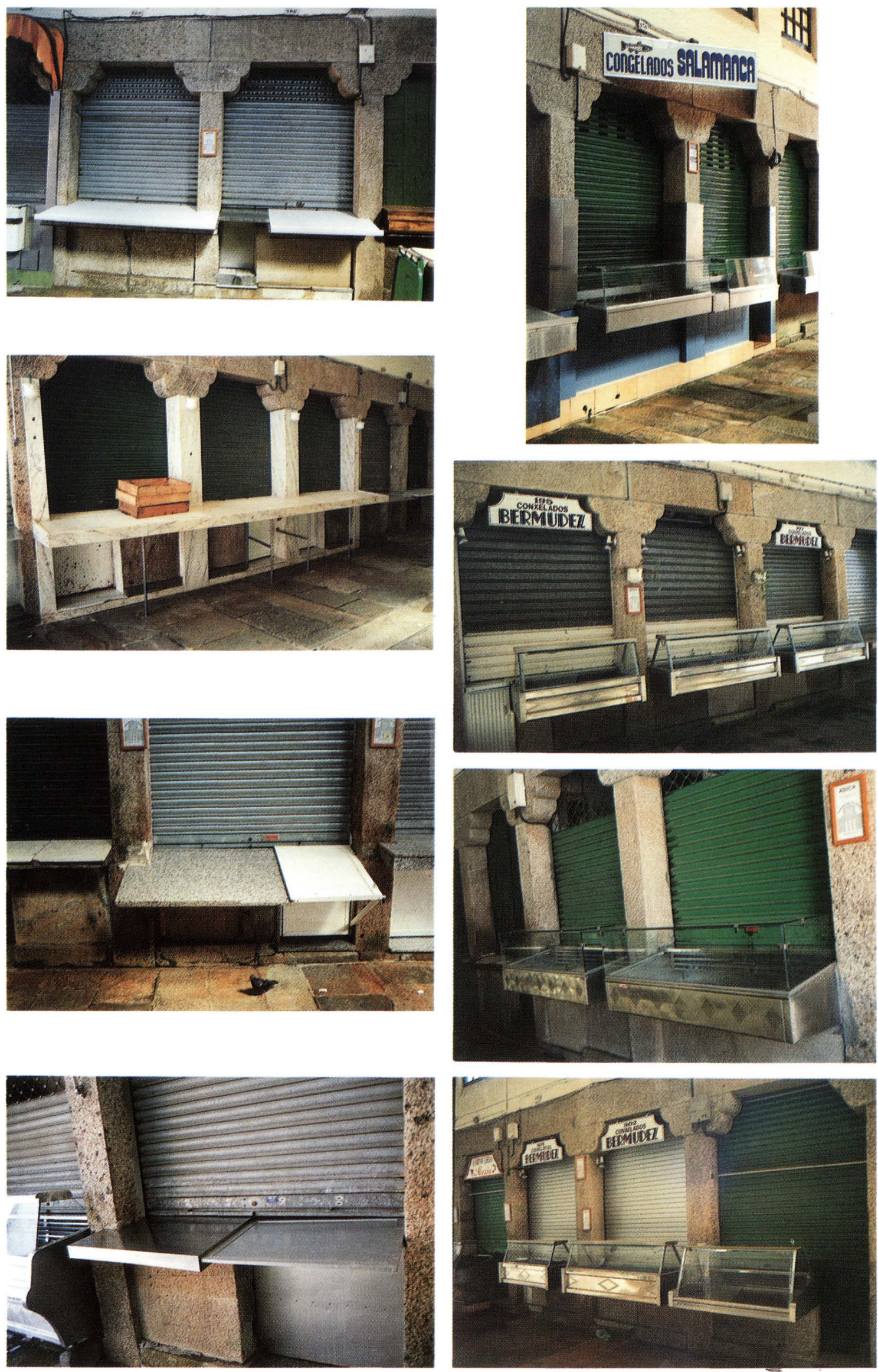

Fig. 30.- Diversos modelos de bandejas de mariscos y de expositores con frio, tipo caja. La foto inferior izquierda muestra comparativamente expositorfrigorifico, modelo I, y cartel, rehabilitados.

(c) Consejo Superior de Investigaciones Científicas 
BANDEJA PARA EXPOSICIOON DE PESCADOS Y MARISCOS (E- 1:40)
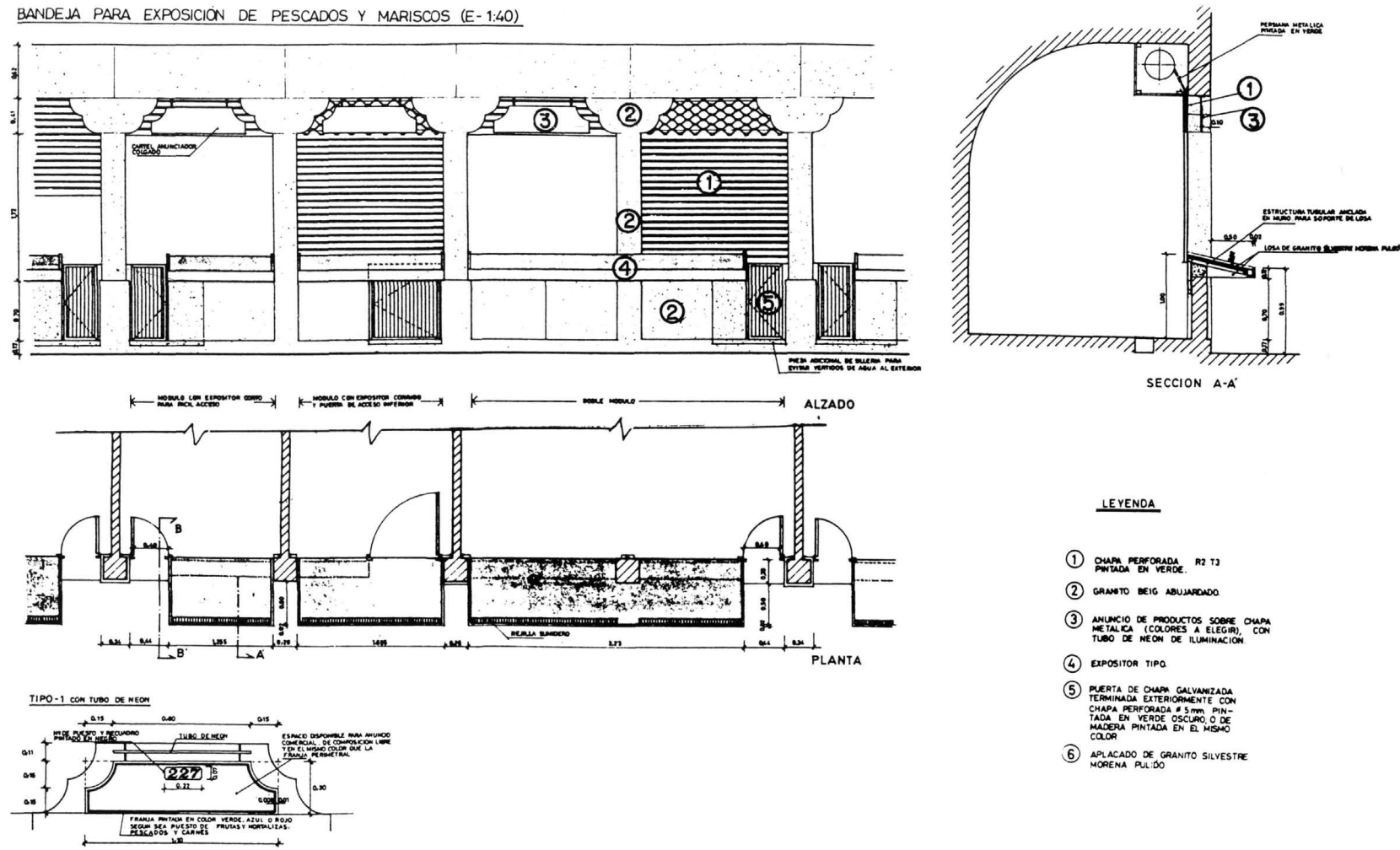

PROTOTIPO DE PUESTO DE VENTA DE LA PLAZA DE ABASTOS
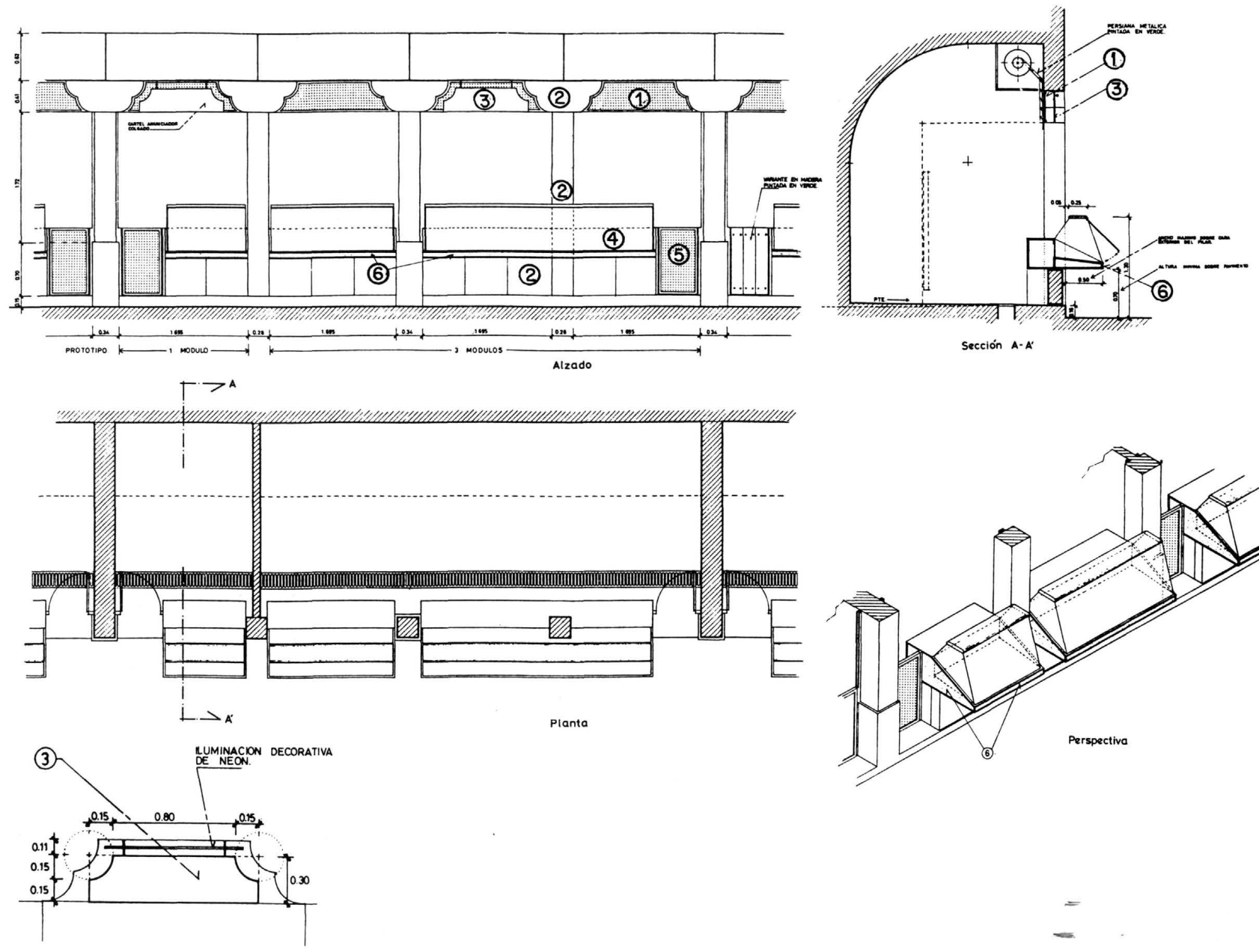

Fig. 31.- Proyecto de bandejas y expositores-frigorificos. 

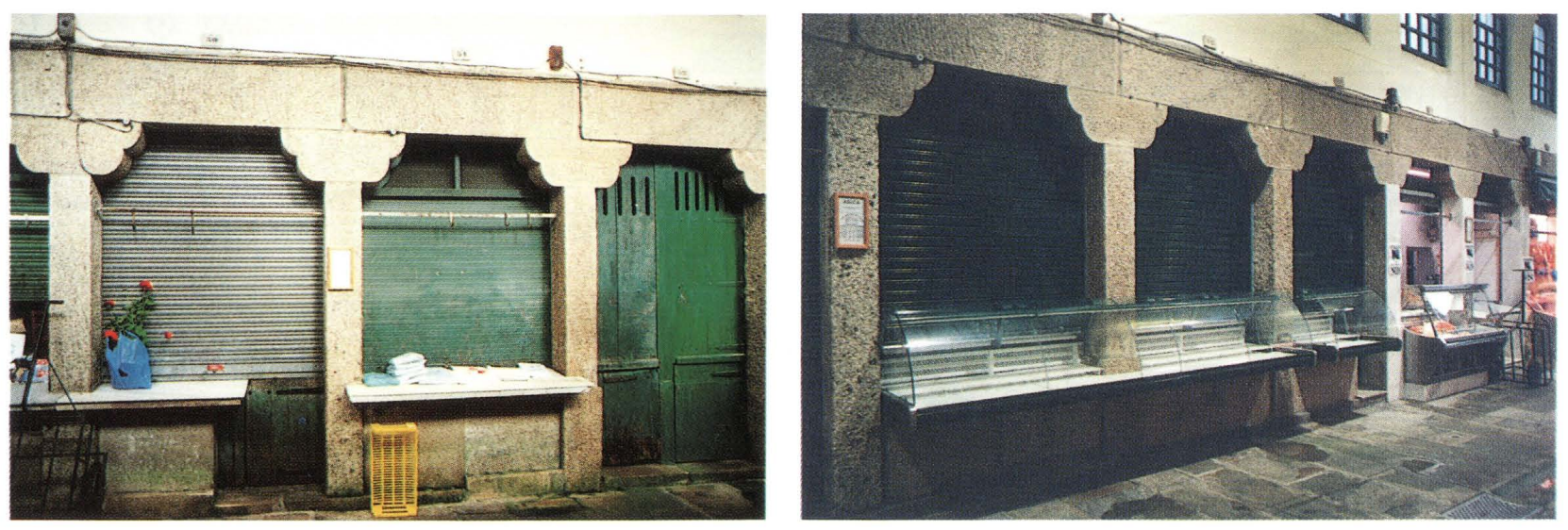

Fig. 32.- Situación precedente y rehabilitada, con expositor-frigorifico, para un usuario de 3 unidades, modelo II.
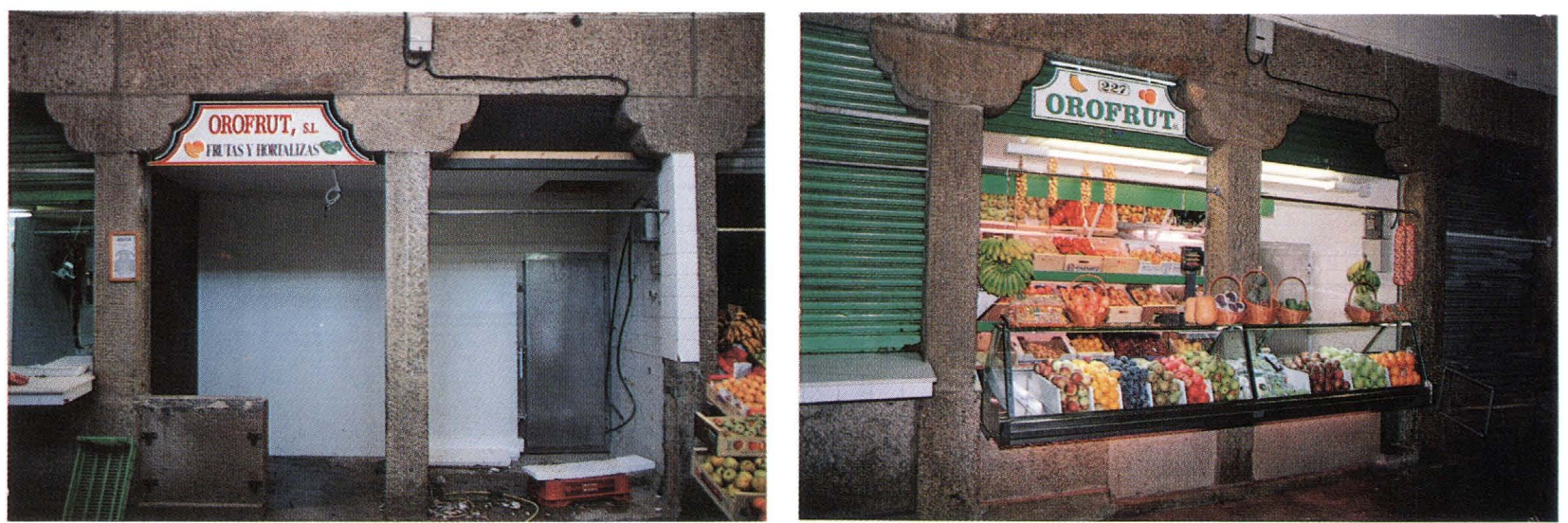

Fig. 33.- Situación precedente y rehabilitada de expositor-frigorifico, s/ modelo I, con modelo de cartel anunciador.
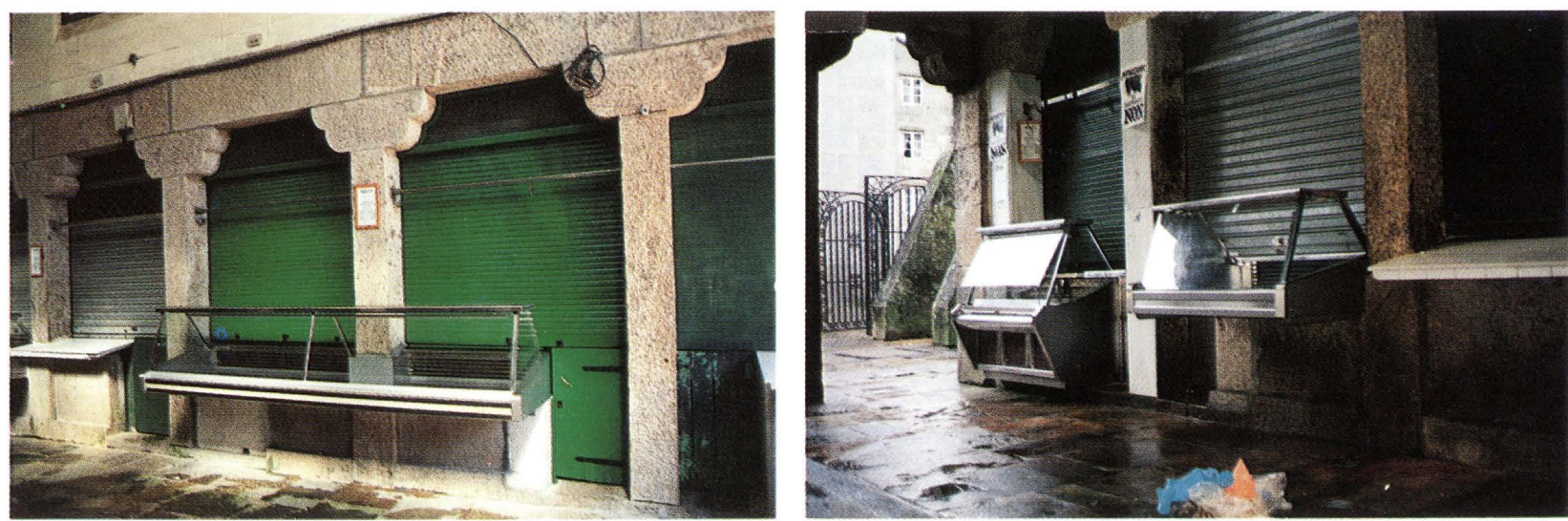

Fig. 34.- Expositores-frigorificos s/ modelo I, de 2 unidades y de 1 unidad.

(c) Consejo Superior de Investigaciones Científicas 

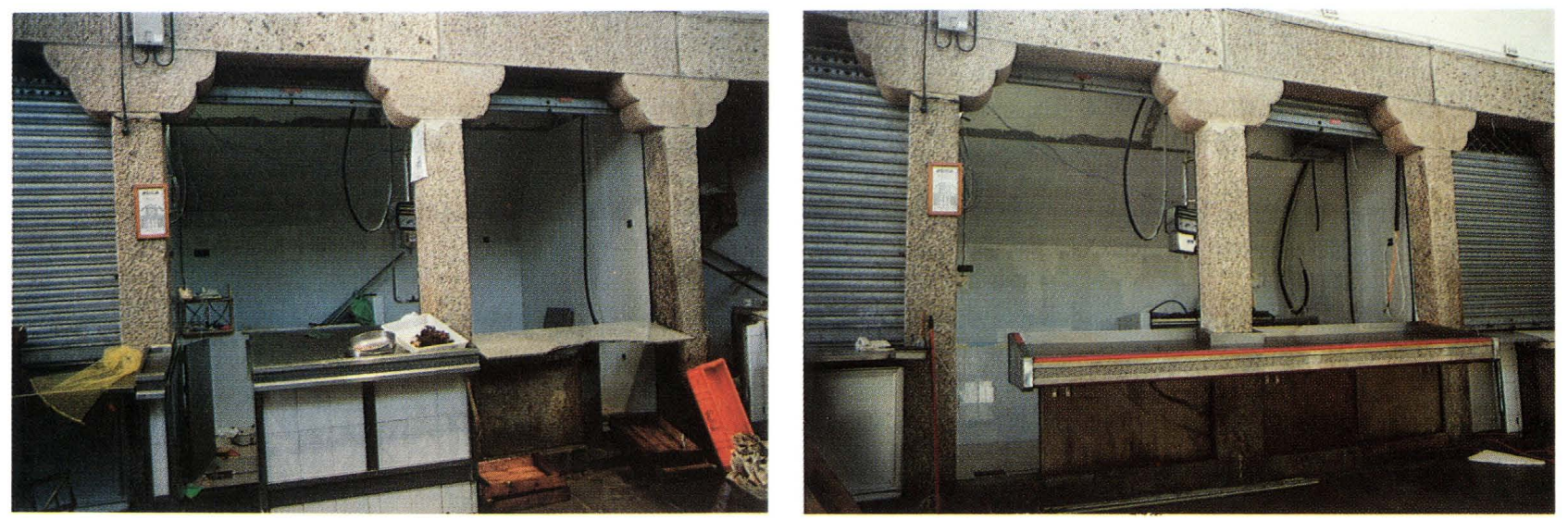

Fig. 35.- Situación precedente y rehabilitada de bandeja para pescados y mariscos, con instalación de frio, 2 unidades.
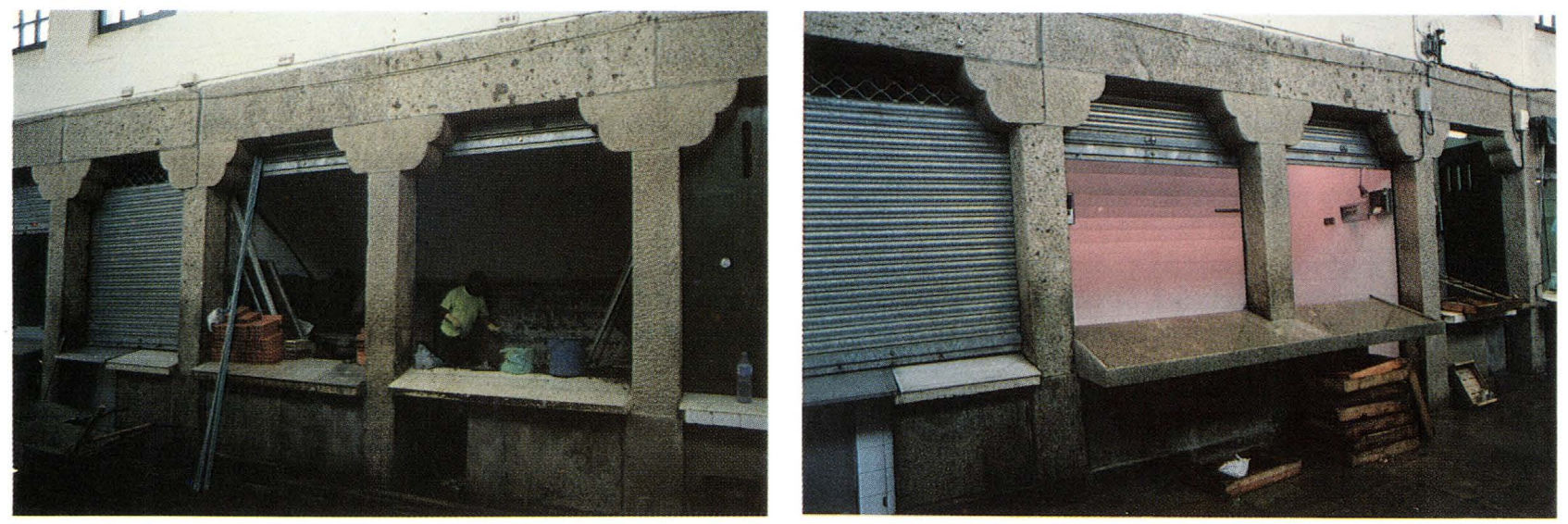

Fig. 36.- Situación precedente y rehabilitada de bandeja para pescados y mariscos, sin instalación de frio, 2 unidades.
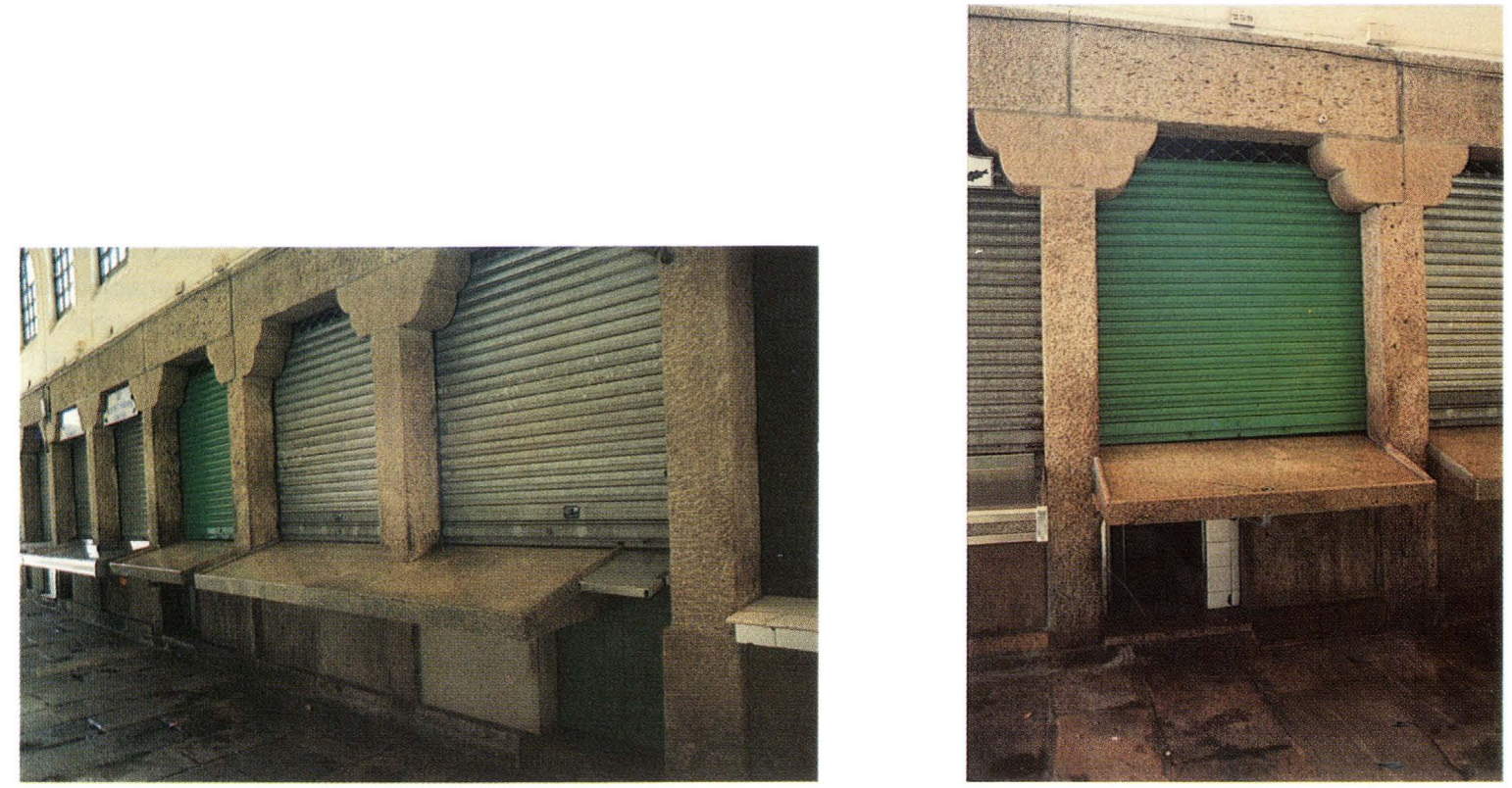

Fig. 37.- Modelos sencillo y doble de bandejas, sin instalación de frio. Serie de 5 unidades rehabilitadas.

(c) Consejo Superior de Investigaciones Científicas 


\section{NOTAS BIBLIOGRÁFICAS}

1) J. MORENAS AYDILLO. Att.: “Outra arquitectura”. Pg. 110 y ss. del lib. 1850 Santiago de Compostela - 1950. P. Costa Bujan y el autor. Colegio Oficial de Arquitectos de Galicia, 1989. Santiago de Compostela (La Coruña).

2) Ordenanzas de Policía Urbana de la Ciudad de Santiago de 1780 (O.P.U. 1780). Publicadas en junio de 1787, todavía vigentes, por la Alcaldía de José Vázquez Quitos. A.M.S.

3) J. MORENAS AYDILLO: "La ciudad reconstruida en el XIX" en edición del lib. "Santiago de Compostela" (1995). Coordinado por Carlos Martí.

4) Libro de Consistorio. 1787. Jun-Sep. - Pág. 130 y ss. A.H.U.S.

5) Sabido es que el edificio ochocentista, hoy Consistorio y Sede de la Presidencia de la Xunta de Galicia, fue terminado en 1772, promovido por el Arzobispo Raxoi, como Seminario de Confesores, con dependencias consistoriales y cárceles, según proyecto del ingeniero Carlos Lemaut. También es sabido cómo hasta junio de 1787 no tuvo lugar el traslado del Consistorio, procedente de su sede en el edificio $n^{\circ} 1$ de la actual plaza de Cervantes.

6) Citado por JULIA GARCÍA-ALCAÑIZ como el arquitecto más importante de Galicia en la época neoclásica. "Arquitectura del Neoclasicismo en Galicia", 1989. Fundación Pedro Barrié de la Maza. La Coruna.

M. MURGUÍA: "España, sus monumentos y artes...Galicia". Barcelona, 1888. Reeditado en Barcelona en 1981.

J. COUSELO BOUZAS: “Galicia artística en el s XVIII...”. Santiago 1932. Pág. 337.

Ma SOCORRO ORTEGA: "El arquitecto Miguel Ferro Caaveiro" C.E.G. Santiago, 1971.

7) C. SÁNCHEZ RIVERA: "Notas Compostelanas". Edit. Sucesores de Galí. Santiago. Pág. 154 y ss.

8) Mazarelo: Mazo para mecer la leche, que tiene una rueda en el extremo del mango ( Pág. 599. Dic Galego-castelan. Edit. Galaxia 1992). ¿ Estará en el origen de esta denominación el uso de este útil, que tuvo que ser un frecuente artículo de venta en la también llamada plaza del Mercado Viejo, todavía a principios del s. XIX, según Sánchez Rivera?.

9) Al buen quehacer de este m.o., se deben entre otras cosas gran número de edificios del casco histórico y las mejores galerías decimonónicas de la ciudad. Se cita como ejemplo significativo, la existente en la planta $2^{\mathrm{a}}$ del edificio $\mathrm{n}^{\circ} 6$ de la calle Virgen de la Cerca (1895). Exposición detallada de la misma, entre otras, en pág. 128 y ss. de la ob. cit. en (1).

10) J.L. CABO VILLAVERDE Y P. COSTA BUJAN: "Imaxe de Compostela". C.O.A.G., 1991. Santiago. Págs. 119 y 120.

11) P. COSTA BUJAN: Art. "Desenvolvemento urbano". Pág. 41 y ss. de ob. cit. en (1).

12) Carta publicada posteriormente en el Boletín $n^{\circ} 20$ de noviembre de 1984 del C.O.A.G., de donde proceden texto e ilustrac ones, agradeciendo las facilidades dadas para esta publicación.

13) Ob. c: n (1).

14) Casualmente, esta similitud también ha sido expresada posteriormente en diciembre de 1993, en la prensa escrita, por J.R. Soraluce Blond, catedrático de la E.S.A. de La Coruña, en su artículo semanal de la Voz de Galicia (serie VI, $\mathbf{n}^{\circ} 140$ ), de la siguiente forma: "Hay, sin embargo, en el Mercado de Santiago, un componente posiblemente inconsciente, aportado por el mismo arquitecto, que lo relaciona con su tierra natal, Asturias. Se trata de una concepción del espacio basilical y de la composición de las fachadas, mucho más próximos a las formas y motivos del prerrománico asturiano, que al románico o al barroco gallego, como él pretendía. Las naves abovedadas de cañón corrido, no vinculan estos locales con ninguna nave catedralicia gallega, sino con el estrecho y alto espacio basilical de San Salvador de Valdediós, así como el tema principal de los alzados con ventanas de triple arco".

15) Lib. del Mercado de Abastos. 1781-1902. Obras adicionales y reparaciones. Pág. 101 y ss. A.H.U.S.

16) Cabe mencionar la habilidad mostrada por la empresa local ARMESA en la construcción de las arquetas, así como el trabajo ejecutado por NEORSA y empresas auxiliares.

\section{SIGLAS}

A.M.S.: Archivo Municipal de Santiago, A.H.U.S.: Archivo Histórico de la Universidad de Santiago; C.E.G.: Єentro de Estudios Gallegos del Instituto Padre Sarmiento, Santiago; C.O.A.G.: Colegio Oficial de Arquitectos de Galicia; A.p.-Archivo particular; co.: construido; a.m.: arquitecto municipal; m.o.: maestro de obras. 